\title{
Retracing the historical evolution of the Portuguese address pronoun você using synchronic variationist data
}

\begin{abstract}
This chapter describes the historical evolution of Portuguese address forms based on regional documents from the Inquérito Linguístico Boléo (ILB) recorded from 1942 to 1974 (University of Coimbra). It focuses on regional and social variation of the vossemecê-você family of address forms. The analysis leads to a (hypothetical) diachronic pedigree of these pronouns as well as to a survey of regional speakers' evaluations of the forms. It concludes that in Portugal there are numerous many-layered islands of address-norm systems that may be understood as a complex system of socioglosses.
\end{abstract}

Keywords: dialectology, Portugal, diachronic reconstruction, geolinguistic variation, você, vossa mercê

\section{Introduction}

This chapter analyzes the diachrony of the vossemecê-você 'Your Grace formal you' family of address forms in order to provide a systematic account of regional and social variation in Portuguese. The analysis is based on unpublished dialect data from Portugal from 1942 to 1974 - the Inquérito Linguístico Boléo (ILB). Basing the analysis on ILB documents showing synchronic variation, this study aims to make a diachronic reconstruction of elements illustrating the development of the series of variants associated with the pronouns vossemecê and its reduced variant, você, used in the present-day standard variety of Portuguese.

Section 2 discusses some theoretical and terminological issues, followed by the presentation of the the ILB corpus in Section 3. Section 4 examines a representative set of data, and Section 5 outlines the morphological diachrony from Latin VOSTRA MERCED to Portuguese você based on the analysis of the ILB corpus data. Section 6 takes the District of Viseu as a representative example of address form choices, and Section 7 outlines a geographical survey of você evaluations across Portugal. Finally, Section 8 summarises the results and findings of the study. 
Given the complexity of address in Portuguese, the glosses and translations of the different terms used for address can only be tentative. The letters $\mathrm{T}$ and $\mathrm{V}$ in cases such as $\mathrm{you}_{T}$ and $\mathrm{you}_{V}$ refer to the informal (close) or formal (distant, polite) relationship expressed by the form of address. If the personal relationship is expressed with the verb only, notations such as come $e_{V}$ may be used. Intermediate terms may appear as, e.g. you ${ }_{V T}$. In general, the terms are only glossed on their first occurrence.

\section{Theoretical considerations}

In undertaking an analysis of Portuguese address forms, there are a number of theoretical questions that need to be addressed.

\subsection{Basic address conventions}

Addressing one another is a universal behavior that is realized interpersonally in a given situation. We make an individual evaluation of the persons in front of us and our relationship with them. These evaluations may be described as positive or negative according to theories of "face" (e.g. Goffman 1959; Brown \& Levinson 1987). Either a speaker intuitively classifies an addressee and treats her/ him accordingly, or strategically chooses an address term in order to voluntarily define or negociate the interpersonal relation. Communities united by language and/or culture may appear to be more or less dynamic in their addressing behavior. The Portuguese address system seems to be a first-rate example of a less static system if we compare it, for example, to the traditional German one, where a change from Sie to $\mathrm{Du}$ among adults is usually controlled by an explicit ceremonial agreement (see Glück \& Koch 1998; Clyne, Norrby \& Warren 2009). In Portugal, you may increase or reduce perceived interpersonal distance by using você instead of $t u$ or $o$ senhor, etc., or simply by switching from third person to second person, and vice versa (see e.g. de Oliveira 2009 and Hummel, in this volume). The most important forms of address in use are: $t u$ 'informal you $\mathrm{T}_{\mathrm{T}}$, você 'respectful but not distant $y_{\mathrm{T} / \mathrm{V}}$ ', $v o(s s e) m e c \hat{e}$ 'forerunner of você used in dialects for roughly the same purpose as você', o senhor/a senhora (very formal you $v$, e.g. you, Sir), amigo/a 'friend', camarada 'comrade, mate', excelência 'Your Excellency', third person form of the verb. 


\subsection{How not to be confused by a third person designating second persons}

In Portuguese, the information conveyed by the grammatical person, gender or number (second or third person/feminine or masculine/singular or plural) does not always match the features of the referential person. Thus, a morphological third person form may refer to the direct interlocutor, which is in fact a referential second person (e.g., $O$ senhor ' $y o u_{V}$ '), a morphological feminine may be used to address a man (e.g., Vossa Senhoria, a former address of high status persons), and a morphological plural can be used to denote a single person (e.g., archaic or regional vós 'sg. you ') '. This study therefore establishes a terminological difference between the person(s) addressed and the grammatical forms used to refer to the person.

The distinction between $1 \mathrm{P}$ (first person singular) to 6P (third person plural) as "morphological persons" (grammatical form) and P_1 (EGO), P_2 (VIS-À-VIS), P_3 (TRACTATUM) (person addressed by reference), etc., as semantic partners in communication, as well as combinations of these, provides unambiguous terms. The terminological set proposed here is based on conceptual deliberations on onomasiology ${ }^{1}$ by Klaus Heger, who referred to the ideas of Karl Bühler in particular (see Heger 1965 and Bühler 1967). Table 1 applies this terminology to Portuguese.

Table 1: Addressing persons ( $\mathrm{n}=$ more persons).

\begin{tabular}{|c|c|c|c|}
\hline \multicolumn{2}{|c|}{ VERBAL FORM (e.g., ir 'go') } & \multirow{2}{*}{$\begin{array}{l}\text { ACTING PERSON(S) } \\
\text { P_1 }\end{array}$} & \multirow{2}{*}{$\begin{array}{l}\text { ADDRESSING } \\
\text { P_1 (inner dialogue?) }\end{array}$} \\
\hline $1 \mathrm{P}$ & (eu) vou 'I go' & & \\
\hline $2 \mathrm{P}$ & (tu) vais 'you go' & P_2 & P_2/P_1 (inner dialogue) \\
\hline $3 P$ & (ela/ele) vai 'she/he goes' & P_3 & P_2 \\
\hline $4 \mathrm{P}$ & (nós) vamos ‘we go' & $P_{-} 1+2 / P_{-} 1+3 / P_{-} 1+2+3$ & $\begin{array}{l}\text { P_1+2+n/P_2 } \\
\text { (vamos! 'let's go') }\end{array}$ \\
\hline $5 \mathrm{P}$ & (vós) ides 'you go' & P_2+n & P_2+n/P_2 \\
\hline $6 \mathrm{P}$ & (eles/elas) vão 'they go' & P_3+n & P_2+n \\
\hline
\end{tabular}

1 The term onomasiology refers to a methodology that looks for linguistic items covering a given conceptual or functional domain, e.g. the lexical fields of 'anger', 'address', and so on. 


\section{3 "Formas de tratamento" and/or "Fórmulas de tratamento"?}

In Portuguese, the distinction between the expressions formas de tratamento 'address forms' and fórmulas de tratamento 'address formulas' is an interesting one. On the one hand, there are formal differences between so-called pronominal forms such as tu/você/vossemecê, and on the other hand, the so-called nominal forms such as o senhor/a senhora or o Manuel/a Maria. At the same time, it is clear that the syntactic positions of these elements show at least two patterns: they are to be found in either the subject or object position within a given sentence. Moreover, they may be rendered prominent as appositions as in Pt. Ó Sr. Manuel, você .../Não se lembra de mim, ti' António? 'You Mr. Manuel, you $\mathrm{v}_{\mathrm{v}}$.../ Don't you remember me, uncle Antonio?' In the linguistic bibliography on Portuguese, the cited nominal address forms may be called formas or fórmulas, no matter whether they are placed as subjects in normal phrases (O Manuel quer ...? 'Manuel, do you $\mathrm{T}_{\mathrm{T} / \mathrm{V}}$ want...'), or rather, as their (preceding or following) appositional counterparts (Ó Senhor Manuel, você ...? 'You Mr. Manuel, do you $\mathrm{v}_{\mathrm{v}}$ want...?'). Moreover, this latter type is often labeled as vocative, ${ }^{2}$ whether it includes a special marker ó or not (cf. for an appellative use without a vocative marker: Dê-me uma codinha, senhora mãe... 'Please give me a piece of bread, mother...' (Aquilino Ribeiro 2015: 115).

This apparent terminological ambiguity led to the search for a better distinction between basic syntactic types of address constructions, and as a result, the following suggestions have been put forward, most recently in Hammermüller (2010):

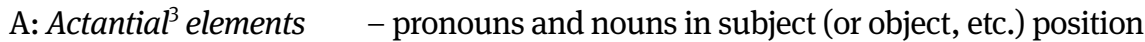

B: Appositional elements - pronouns and nouns in adjunctive position

C: Appositional vocatives - forms as in B, but with vocative markers like ó

The following examples illustrate distinction.

A Actantial Address Forms

A-1 Nominal Address

O Senhor está bom? 'Are you ${ }_{\mathrm{v}} \mathrm{ok}, \mathrm{Sir}$ '’

A-2 Pronominal Address

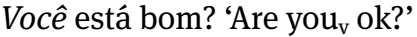

A-3 Verbal Address

Estás bom? 'Are you $\mathrm{T}_{\mathrm{T}} \mathrm{ok}$ ?'

2 Portuguese has the specific vocative morpheme ó (open vowel [0]). It must not be confused with the masculine singular definite article $o$ (pronounced $[\mathrm{u}]$ ). As a consequence, ó pai 'You, father/ Hey, father' has to be distinguished from o pai 'lit. the father'. Both are used for address. In this chapter, the former is glossed as 'You, father' (vocative), the latter as 'Father' (simple address). 3 Other terminologies would use the term syntactic arguments instead of actantial elements. 
B Appositional Address Forms (Pt. apelemas 'appealing forms')

B-1 Nominal Appealing Forms Está tudo bom, Sr. Fulano? 'Everything ok, Mr. X?'

B-2 Pronominal Appealing Forms Tu!, estás bom? 'And you $\mathrm{u}_{\mathrm{T}}$, are you $\mathrm{w}_{\mathrm{T}}$ ok?'

B-3 Verbal Appealing Forms Esteja quieto! 'Be $\mathrm{v}_{\mathrm{V}}$ quiet' (polite)

(imperative)

C Appositional Vocatives (forms as in B, but with vocative markers like ó)
C-1 Nominal Vocatives
Está tudo bom, ó Sr. Fulano?
C-2 Pronominal Vocatives
Ó tu!, estás bom?
C-3 Verbal Vocatives
^Olá, venha cá! 'Hey, come $\mathrm{v}_{\mathrm{V}}$ here'

\subsection{Elaborating onomasiological tools for specific address studies}

For the analysis of the ILB corpus with respect to historical traces of Portuguese address forms, it is necessary to choose the best adapted methodological tools and terminology. The term for address forms in Portuguese is formas de tratamento, literally 'forms of treatment'. Fundamentally, speakers experience verbal address as an immediate and more or less direct treatment by their interlocutor. An addressee can take this treatment positively or negatively, so that - by the speaking self (EGO) - it has to be seen as a more or less immediate access to the other person (VIS-À-VIS). In order to prevent the respective inventory of onomasiological concepts from being too near to tautology, valid conceptual instruments are required that represent a special meta-language. The interlingual definitions of these conceptual terms should be able to establish functional tertia comparationis (that is, a common point of reference that allows comparison) as linguistic tools for onomasiological and/or contrastive investigation in the domain of address (and others).

\subsection{The concept of RESPECT as an onomasiological tool}

Linguistic analysis in the domain of address has led many investigators to discover the relevance of concepts such as "respect", "reverence”, "veneration", "courtesy”, "politeness", and others (see Hummel, in this volume). These mostly Latin-based philosophical terms have been accepted as being rather universal at least for an enlarged European context (cf. the keyword respect in the Stanford Encyclopedia of Philosophy). They seem to have proved helpful for the description of the necessary conditions regarding address. Trying to establish a useful 
intercultural tertium comparationis, they enable us to evaluate (and to accept or not) the way in which we are addressed. In particular, the widely accepted (because of being less polysemic?) term of respect seems to offer itself as first choice for onomasiological research in the field of address forms and conventions, as we shall see below. ${ }^{4}$

Without claiming to have a perfect conceptual hypothesis for the wider field of address, I propose a suitable approximation for the initial analysis of the relevant ILB data. The aim is to discover specific language development implications in the domain of the descendants of late medieval vossa mercê. As a first step, it will be useful to distinguish the categories of in-group and out-group addressees (or: insiders vs. outsiders) as well as those of older and/or higher status addressees. The two types can be compared in order to show possible affinities. Table 2 presents some typical examples (all based on occurrences in the ILB database) used in north-eastern parts of Portugal, but also elsewhere.

Table 2: Respect Matrix (core groups in bold).

\begin{tabular}{lll}
\hline Respect Matrix & In-group & Out-group \\
\hline older people & ó pai/mãe, você quer ...? & o Sr./a Sr.a quer ...? \\
\hline higher status individuals & ó patrão, você quer ...? & ó mestre, você quer ...? \\
\hline children \& youth & $t u$ & o/ a menino/a \\
\hline equals (school/workmates) & tu, vocêe & você, tu \\
\hline older (parents/godparents) & ó pai/mãe, você quer ...? & o Sr./a Sr.a quer ...? \\
\hline older (without direct kinship) & vossemecê, vomecê & o Sr. / a Sr.a quer ...?, você \\
\hline superiors & ó patrão, você quer ...? & ó mestre, você quer ...? \\
\hline lower status & tu, você, tiazinha & você, santinha, tiazinha \\
\hline
\end{tabular}

In order to reduce complexity, I propose a simplification with regard to some basic categories. It might be useful to have special distinctions at least for younger people, equals, and older people outside one's family, as well as a complementary categorization of higher status and lower status addressees. Although this presentation of types of address remains limited, it shows how it is possible to gradually refine onomasiological tools needed for specific purposes.

4 Here we may possibly include non-European languages like Turkish, where sayg means 'respect, esteem' and is close to 'politeness', as is shown by the derived adjective saygiyla 'polite'; found in Langenscheidt's Online Dictionaries [accessed 7 July 2017]. 


\section{The Inquérito Linguístico Boléo (ILB)}

The ILB Archives of the Faculdade de Letras at the University of Coimbra constitute a rich collection of regional language and ethnographic data from all over Portugal (Boléo 1942/1974). They comprise about 3,100 questionnaires (plus complementary documents) completed between 1942 and 1974 by Manuel de Paiva Boléo, Professor of Romance philology and Portuguese linguistics at Coimbra (see Hammermüller 1995). The documents contain two types of spoken language data obtained from local native speakers.

The first set of data was produced in 1942. Boléo posted out a huge number of questionnaires (in total around 15,000 copies were printed) to primary school teachers and local village priests, with the majority going to the north and the center of Portugal (Boléo 1942/1974). This first printed version (with 550 items) of the questionnaire had 1,829 completed returns (Boléo 1974: 322).

A second set of data was collected by Boléo's students after a theoretical and practical introduction to dialectological methods in the second year's part of their Introdução aos estudos de filologia/linguística ( $2^{a}$ parte) 'Introduction to the study of philology/linguistics (part II)' (Boléo 1974: 322-323). From 1942 onwards, ${ }^{5}$ Boléo's students were required to undertake fieldwork, using an expanded 1942 questionnaire with up to 757 items (see last edition in 1978 of the 3rd version by Fátima Matias, University of Aveiro).

The results gathered via questionnaire constitute the Inquiry (Inquérito). From 1945 to 1974 (the year Boléo retired from teaching), his students were also asked to write up a Relatório, which described their local experiences and documented ethnographic and language facts they found worthwhile recording. Most of the original copies are still conserved in Coimbra, with a total of approximately 3,100 Inquéritos and 1,800 Relatórios.

The ILB database can be seen as nothing less than a linguistic (and ethnographic) bonanza for diachronic reconstruction based on synchronic variation. The data enable us to analyze oral forms of address conserved by a rural milieu (at least to a very large extent) which was - up to the second half of the 20th century - still widely marked by illiteracy. This derives from the fact that in Portugal the general school system (promoted during teachers' education in Escolas de Magistério in many district capitals) had only slowly been developed from the first half of the 20th century onwards, as illustrated by the picturesque description of a regional school by Gibbons (1984). The data thus reproduce the limited literacy of rural, lower status speakers (and as a product of internal migration, also of urban speakers).

5 For 1942, we found at least two Inquéritos already completed by students. 


\section{Address forms (e.g. você) and their use in ILB questionnaires}

Exploring the ILB data from 1942 onwards, Boléo and collaborators produced more than 160,000 excerpted words on paper sheets and a huge number of published and unpublished memoirs and theses written by their students (cf. Boléo 1971b, 1976, 1979). However, these efforts never led to the realization of Boléo's original idea of producing a Dicionário do Português Regional (first in 1959), proposed also as DFPM (Dicionário dos falares portugueses modernos) (cf. Boléo 1959, 1971a, 1976: 8; Hammermüller 1995). The following sections present parts of the ILB corpus that shed some light on the geolinguistic remnants of address forms used up to the latter part of the 20th century.

Table 3 provides an abstract map of continental Portugal including the districts used to classify the data (see Hammermüller 2011: $\S$ 5.1). The numbers go from north (1) to south (8), including the two archipelagos in the Atlantic Ocean (9), and the names refer to districts (see map of Portugal in Lara, this volume).

Table 3: Districts of Portugal.

\begin{tabular}{llll}
\hline $\begin{array}{l}\text { North (1) } \\
\text { to South (8) } \\
\text { plus islands (9) }\end{array}$ & West & Middle & East \\
\hline 1 & $\begin{array}{l}\text { VIANA DO } \\
\text { CASTELO }\end{array}$ & & BRAGANÇA \\
\hline 2 & PORTO & BRAGA & VILA REAL \\
\hline 3 & AVEIRO & VISEU & GUARDA \\
\hline 4 & COIMBRA & & \\
\hline 5 & LEIRIA & & CASTELO BRANCO \\
\hline 6 & LISBOA & SANTARÉM & PORTALEGRE \\
\hline 7 & SETÚBAL & ÉVORA & BEJA \\
\hline 8 & & FARO & \\
\hline 9 & AÇORES & & MADEIRA \\
\hline
\end{tabular}




\subsection{The questions}

This section presents an analysis of ILB summaries of address usage in the third edition modified by Boléo's former student Fátima Matias. ${ }^{6}$ Table 4 sets out the questions in the ILB survey dealing with forms of address (see Matias 1978: ILB-§ $371+\S 371 \mathrm{~b}($ pages $75 / 75 \mathrm{~A}))^{7}$

Table 4: Questions about address in the ILB questionnaire.

\section{1 tratamento}

[1] Quando os filhos chamam os pais, os avós, os padrinhos, dizem: ó pai? ó meu pai? ó sr. pai? ó sr. padrinho?

[2] Quando se lhes dirigem, como os tratam: por vossemecê?

[3] Quando falam deles na ausência dizem: a mãe está doente ou a minha mãe está doente?

[4] Usa-se dizer, em conversa com uma pessoa de condição social superior, o sr. seu pai, a $s r^{a}$. sua mãe?

[5] É costume tratar o irmão ou irmã mais velha por mano, mana?

'371 address

[1] When children call their parents, grandparents, godparents, do they use: you father? you my father? you senhor father? you senhor godfather?

[2] When children address these people, what do they use: vossemecê?

[3] What do children use to refer to these people if the latter are absent: mother is sick or my mother is sick?

[4] What is usually chosen in conversations with higher status people, senhor your father, senhora your mother?

[5] Do you usually address your older brother or sister with mano, mana (short forms of irmão 'brother' and irmã 'sister')'

Outras observações: p.ex.: se é costume as crianças pedirem a benção quando encontram o padrinho ou o pároco da terra:

[6] deite-me a sua benção, meu padrinho, e qual a resposta destes

[7] (Santinho!, Deus te abençõe, etc.).

6 Matias went back to a second edition by Boléo from 1962 (probably to its reprint in 1963) where the exploration of tratamento given in section $\S 371$ had been complemented by another section, $\S 371 \mathrm{~b}$, in order to broaden the inquiry to include extra-familiar address. But, apparently, Boléo had already proposed earlier a longer list of additions when preparing his students for their fieldwork. So $\S 371 \mathrm{~b}$ had already appeared before (and was added by hand to the printed text of the 1942 questionnaire as "371-5: Indicar as fórmulas de tratamento para com estranhos (você, vossemecê, patrãozinho, senhor, etc.)”.

7 For practical reasons numbers from [1] to [7] have been assigned to the questions in § 371 . 
Table 4 (continued)

'Further observations: e.g. if children ask for a blessing when they meet their godfather or the village priest:

[6] may / receive your blessing, my godfather, and what do they answer

[7] (Santinho! 'Saint + diminutive -inho', God bless you, etc.)'

371b Indicar as fórmulas de tratamento para com estranhos: você (é ofensivo este tratamento?), vossemecê, patrãozinho, senhor, santinha, etc.

'371b Indicate the forms of address used with strangers: você (would this be offensive?), vossemecê 'you ${ }_{\mathrm{VT}}$ ', patrãozinho 'boss + diminutive', senhor 'Mister, Sir', santinha (feminine form of Saint plus feminine form of the diminutive -inha)'

\subsection{Questionnaire responses}

The ILB summaries refer to several locations within Portuguese districts ordered from north to south. The answers come from different years, and illustrate a variety of address form uses that - at first glance - do not show much regularity concerning geolinguistic, sociolinguistic and transgenerational developments. Rather, it can be observed that the individual locations (mostly consisting of villages) have (or at least had) a social life of their own, using their own system of address accordingly. When looking at the regional distribution of different pronounciations, e.g. the bilabial onset [v-, b-], it must be borne in mind that many of the fieldworkers writing down the file cards, and particularly those inquiries completed by correspondence from 1942, may have preferred to follow the standard spelling, e.g. (standard) initial $<\mathrm{v}->$ orthography.

(1) Afife (Viana do Castelo)

371: É curioso em Afife o tratamento quase familiar entre todas as pessoas. Os mais velhos tratam por $t u$ todos os mais novos, e os de igual idade, tambem se tratam por $t u$. Os novos tratam os mais velhos por «tios», salvo, é claro, os de certa representação social. Quando os filhos chamam os pais, o padrinho, o avo dizem: <ò mêu pài, ò padriñu, ò mêu abô $>^{\star}$. Quando se lhes dirigem tratam-us por < bòsê $>$.

'The striking fact in Afife is the almost familiar treatment of all people. The oldest address the youngest with $t u$ ' $\mathrm{you}_{\mathrm{T}}$ ', and people of the same age also use $t u$. Young people address old people with 'uncle', with the obvious exception of higher status people. When the children address their parents, godfather or grandfather, they say: <you my father, you my godfather, you my grandfather ${ }^{\star}$. When they address them they use <bòsề^ (variant of você ' $\mathrm{you}_{\mathrm{VT}}$ ')' 
371b: < bòsê >* (não sendo ofensivo) e <bòsəməsê >*

'<bòsề (variant of você 'you ${ }_{\mathrm{vT}}$ ', which is not offensive) and <bòsəməsê>* (variant of vossemecé ' $\mathrm{you}_{\mathrm{VT}}$ ')'

Table 5: Forms of address used in Afife (Viana do Castelo). ${ }^{8}$

\begin{tabular}{|c|c|c|c|c|c|c|}
\hline Categories & $<->$ young $^{8}$ & <->equals & $>$ parents & > older & > strangers & > superiors \\
\hline appellative & & & ó meu pai & tio/a & & \\
\hline actantial & $t u, 2 \mathrm{P}$ & $t u, 2 \mathrm{P}$ & vo(sse)mecê & vo(sse)mecê & & \\
\hline
\end{tabular}

ILB-0112/64_Afife/Afife/Viana do Castelo/VIANA DO CASTELO [Q ${ }^{21962]^{9}}$

(2) Antela (Porto)

371: o tratamento geral é de você, ó pai, ó mãe (senhor pai caiu já em desuso)^. 'the general form of address is você, ó pai 'you father', ó mãe 'you mother' (senhor pai has fallen out of use)'

371b: O tratamento de você é geral e de modo nenhum ofensivo. É vulgar quando se fala com uma pessoa mais nova, é vulgar tratá-la por netinho e se fôr mais velha, <abuziñu ${ }^{\star}$.

'Você is generalized and not offensive at all. It is vulgar to address a younger person with netinho 'grandson' and older people with <abuziñu> [= avô 'grandfather' + diminutive -inho]'

Table 6: Forms of address used in Antela (Porto).

\begin{tabular}{|c|c|c|c|c|c|c|}
\hline Categories & <-> young & <->equals & $>$ parents & > older & > strangers & > superiors \\
\hline appellative & & & ó pai/mãe & tio/a; avozinho & & \\
\hline actantial & & você & você & você & & \\
\hline
\end{tabular}

ILB-0863/65_Antela/Lavra/Matosinhos/PORTO [Q 21962]

8 <-> means 'between', < means 'directed to'.

9 This is the ILB identification number. It provides the year of the inquiry after the slash, e.g., ILB-0112/64 equals the year 1964. The identification number is then followed by the indication of "locality/community/canton/DISTRICT", plus the edition of the questionnaire [Q ${ }^{21962}$. Intentionally omitted parts of recorded responses are marked by [...]. The symbol <...>* (i.e., followed by an asterisk) means a slightly modified reproduction of the original phonetic transcription, where $<\grave{o}>$ represents an open vowel and $\langle\hat{\mathrm{o}}>$ a closed vowel; $\langle\mathrm{S}\rangle$ corresponds to the Sampa-code for the sibilant [J]. 
(3) Nevogilde (Porto)

371: $\quad$ tratamento entre iguais é: bòsê - Bocê faça-me isto. Bocê disse aquilo.

'The address term used between equals is bòsê (= você $)$ - Bocê, please do this for me. Bocê, you said those things'

371b: O tratamento por você não é de modo algum depreciativo. Vossemecê é um tratamento respeitoso que se dá a pessoas de categoria mais elevada.

'Você is not derogatory at all. Vossemecê is used to respectfully address higher status people’

Table 7: Forms of address used in Nevogilde (Porto).

\begin{tabular}{lllllll}
\hline Categories & <-> young & <->equals & > parents & > older & > strangers & > superiors \\
\hline appellative & & ó pai/mãe & tio/a & & \\
\hline actantial & você & você & você & vocêe & vossemecêe \\
\hline
\end{tabular}

ILB-0867a/49_Nevogilde/Nevogilde/Porto (Foz)/PORTO [Q 1942]

(4) Foz do Douro (Porto)

371: Quando se dirigem aos pais ou familiares mais velhos dizem apenas: $<$ Pai ou u pai fieS iStu?>^. Tratam os irmãos mais velhos pelo nome próprio, sem fazer distinção em relação aos mais novos.

'When they address their parents or older relatives, they only say: <father or you father, have you done this?> They address their older siblings with their first name, without marking any difference regarding the younger ones'

371b: Dizem quando se dirigem a estranhos: $<$ u siñuar $>^{\star}$. A uma mulher mais idosa podem dizer: <sãntiña ${ }^{\star}$.

'With strangers they use $<\mathrm{u}$ siñuar $>$ (= O senhor - 'you, Sir'), with an old woman they may use <sãntiña (= Santinha 'Saint + diminutive')'

Table 8: Forms of address used in Foz do Douro (Porto).

\begin{tabular}{lllllll}
\hline Categories & <-> young & <-> equals & > parents & > older & > strangers & > superiors \\
\hline appellative & name & name & pai/mãe & tio/a & & \\
\hline actantial & & você & opai/amãe & você & o senhor & o senhor* \\
\hline
\end{tabular}

ILB-0870/67_Foz do Douro/FdD/Porto/PORTO [Q ${ }^{21962]}$ 
(5) Aveiro (Aveiro)

371: É uso chamarem: ó pai! ó bó! ó padrinho! Há quem use tratar os pais por você mas geralmente é só: ó pai faz-me isto ou aquilo.

'Usual terms are ó pai! ó bó! 'you, grandfather', ó padrino ‘you, godfather'. Some use você for addressing their parents, but normally they say: $y_{0} u_{\text {, }}$ father, do ${ }_{T}$ this or that'

Table 9: Forms of address used in Aveiro (Aveiro).

\begin{tabular}{|c|c|c|c|c|c|c|}
\hline Categories & <-> young & $\langle->$ equals & $>$ parents & > older & > strangers & > superiors \\
\hline appellative & & & ó pai & tio/a & & \\
\hline actantial & & & o pai/você & & & \\
\hline
\end{tabular}

ILB-1069/44_Aveiro/Aveiro/Aveiro/AVEIRO [Q 1942]

(6) Corujeira (Viseu)

371: hoje chamam meu pai, minha mãe, meu padrinho etc. Ha poucos anos ainda era snr pai, senhora mãi e, quando falavam a alguem - o Snr seu pai, etc. Usam o vossemecê quando falam a alguem superior, você menos cerimonhoso.

'at present meu pai, minha mãe, meu padrinho, etc. are used. A few years ago, snr pai, senhora mãi, and, speaking to other people - o Snr seu pai 'senhor

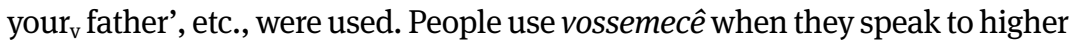
status persons; você is less ceremonial [formal]'

Table 10: Forms of address used in Corujeira (Viseu).

\begin{tabular}{|c|c|c|c|c|c|c|}
\hline Categories & ২-> young & <->equals & $>$ parents & $>$ older & > strangers & > superiors \\
\hline appellative & & & meu pai & & & \\
\hline actantial & & & você & & & vossemecê \\
\hline
\end{tabular}

ILB-1273/42_Corujeira/Ventosa/Vouzela/VISEU [Q 1942]

(7) Vilharigues (Viseu)

371: $\quad<$ meu pai $>^{\star}$. Os ricos dizem $<$ senhor pai $>^{\star},<$ meu padriñu $>^{\star}$. Padrinho de posição social superior: <senhor padriñu $>^{\star}$.

' $<$ my father $>$. The rich say $<$ senhor father $>$. $<$ my godfather $>$. If the godfather is a higher status person: <senhor godfather $>$ ' 
371b: tu - para os da mesma idade e condição. <bòsê, bòsəməsê> - para as pessoas mais ricas e mais velhas. <səñôra > para posição social superior.

' $\mathrm{you}_{\mathrm{T}}$ - for people of the same age and social condition. <bòsê, bòsəməsê> (=você, vossemecê $)$ - for richer and older people. Senhora for higher status people'

Table 11: Forms of address used in Vilharigues (Viseu).

\begin{tabular}{|c|c|c|c|c|c|c|}
\hline Categories & $<->$ young & <-> equals & $>$ parents & > older & > strangers & > superiors \\
\hline appellative & & & $\begin{array}{l}\text { meu pai } \\
\text { sr. pai } \\
\text { (< ricos) }\end{array}$ & & & senhora \\
\hline actantial & tu & tu & você & $\begin{array}{l}\text { você, } \\
\text { vossemecê }\end{array}$ & vossemecê & vossemecê \\
\hline
\end{tabular}

ILB-1274/63_Vilharigues/Paços/Vouzela/VISEU [Q 21962]

(8) Várzea (Viseu)

371: Quando os filhos chamam os pais, dizem: ó sr. pai!, ó senhora mãe. Quando se lhes dirigem: Bomecê!

'Children calling their parents say: you senhor father, you senhora mother. Simply addressing them, they use Bomecê! (Vossemecê!)'

5) Indicar as fórmulas de tratamento para com estranhos (você, vossemecê, patrãozinho, senhor, etc.): a senhora; patrãozinho; patroa; bomecê.

'Forms of address used with strangers (você, vossemecê, patrãozinho, senhor, etc.): a senhora; patrãozinho '(male) boss + diminutive -(z)inho)'; patroa '(female) boss'; bomecê'

Table 12: Forms of address used in Várzea (Viseu).

\begin{tabular}{|c|c|c|c|c|c|c|}
\hline Categories & <-> young & <-> equals & > parents & > older & > strangers & > superiors \\
\hline appellative & & & ósr.pai & & senhora & patrão \\
\hline actantial & & & vomecê & vomecê & vomecê & vomecê \\
\hline
\end{tabular}

ILB-1287/59_Várzea/Calde/Viseu/VISEU [Q 1942 + (5)]

(9) Celas (Coimbra)

371: ó pai?, você 'you, father, you' 
Table 13: Forms of address used in Celas (Coimbra).

\begin{tabular}{|c|c|c|c|c|c|c|}
\hline Categories & $\langle->$ young & <->equals & $>$ parents & > older & > strangers & > superiors \\
\hline appellative & & & ó pai & & & \\
\hline actantial & & & você & & & \\
\hline
\end{tabular}

ILB-1685/42_Celas/Olivais/Coimbra/COIMBRA [Q 1942]

(10) Tovim de Baixo (Coimbra)

371-(5): O tratamento mais corrente é por vossemecê. Se alguém trata outro com quem não tem grande confiança por você levam a mal. De igual modo se se tratar de pessoas a quem por natureza se deve respeito como os pais ou outras pessoas de família. A maneira como esse tratamento lhes repugna aparece com nitidez nesta expressão: bòsê è iStrubaria!

'The usual form of address is vossemecê. If people do not feel confident, a person addressed with você may hold it against the speaker. The same happens addressing people who deserve respect, e.g. the parents or other members of the family. The rejection of this form of address is clearly expressed by the locution você è estrubaria! 'você is crap' [that is, connoted with stable and dung, see fn. 9].

Table 14: Forms of address used in Tovim de Baixo (Coimbra).

\begin{tabular}{lllllll}
\hline Categories & <-> young & <->equals & > parents & > older & > strangers & > superiors \\
\hline appellative & & & & & \\
\hline actantial & você (?) & vossemecê & vossemecê & vossemecê & vossemecêe \\
\hline
\end{tabular}

ILB-1687/55_Tovim de Baixo/Sto. António dos Olivais/Coimbra/COIMBRA [Q 1942]

(11) Sacavém (Lisbon)

371: Os filhos chamam: Ó pai! Ó meu pai? Quando se lhes dirigem tratam-nos por bòcê e bossemecê. [...] Quando se dirigem a pessoas de categoria dizem: V. Ex. ${ }^{a}$.

'The children call their parents: you, father! you, my father? When simply addressing them, the children use bòcê and bossemecê (= você and vossemecê). [...] When they address higher status people: Vossa Excelência 'Your Excellency" 
Table 15: Forms of address used in Sacavém (Lisbon).

\begin{tabular}{|c|c|c|c|c|c|c|}
\hline Categories & <-> young & <-> equals & $>$ parents & > older & > strangers & > superiors \\
\hline appellative & & & $o ́$ (meu) pai & & & \\
\hline actantial & & & vo(sseme)cê & & & V.Ex.ia \\
\hline
\end{tabular}

ILB-2090/42_Sacavém/Sacavém/Loures/LISBOA [Q 1942]

(12) Negrais (Lisbon)

371: dizem ó pai; ó velha, ó velhinha (para a avó); ó sr. padrinho (para o padrinho). Quando se lhes dirigem tratam-nos por vossemecê. [...] É muito vulgar tratar-se o irmão ou a irmã mais velha por mano ou mana.

'If they call them, they use ó pai; ó velha 'you, old lady', ó velhinha ('you, old lady' + feminine diminutive -inha; for their grandmother), ó sr. padrinho (for their godfather). To simply address them they use vossemecê. [...] It is considered very vulgar to address the older brother or sister with mano or mana [shortened forms of irmão 'brother' irmã 'sister']'

371b: o tratamento por você não é ofensivo. O mais usado é vossemecê. Tb. o senhor quando é para alguém de certa ceremónia. Tb. usam patrão.

'Using você is not offensive. Most used is vossemecê. Also o senhor in formal contexts. Also use patrão 'boss”'

Table 16: Forms of address used in Negrais (Lisbon).

\begin{tabular}{|c|c|c|c|c|c|c|}
\hline Categories & <-> young & <-> equals & $>$ parents & $>$ older & > strangers & > superiors \\
\hline appellative & & & ó pai & ó velh(inh)a & & patrão \\
\hline actantial & & você & vossemecê & vossemecê & & o senhor \\
\hline
\end{tabular}

ILB-2091/68_Negrais/Almargem do Bispo/Sintra/LISBOA [Q 21962]

(13) Linhó (Lisbon)

371b: <vòsê>* é a forma de tratamento mais generalizada. Os filhos tratam os pais pelos diminutivos - <pajziñu, mãjziña $>^{\star}$. O uso tratar-se os pais por $t u$ começa a infiltrar-se na gente simples o que escandaliza os mais antigos. $\mathrm{O}$ tratamento de mano começa a ser dado aos cunhados talvez por influência algarvia. Os enteados tratam o padrasto e a madrasta por tio e tia. O tratamento de compadre usa-se entre os pais e os padrinhos dos filhos daqueles e ainda entre os festeiros [feStêruS] ${ }^{\star}$ - os que participam em festas dos santos populares contribuindo com uma certa quantia de dinheiro. 
'<vòsê $>^{\star}(=$ você $)$ is the most usual form of address. Children address their parents as <pajziñu, mãjziña $>^{\star}$ (= paizinho 'father + diminutive', mãezinha 'mother + diminutive'). The custom of addressing their parents with tu starts to appear in lower status families, not without shocking the older people. Mano (short form of irmão 'brother') starts to be used amongst brothers-inlaw - a possible influence from the Algarve. Stepchildren address their stepfather or stepmother with tio 'uncle' and tia 'aunt'. Compadre is used between parents and godfathers (it also denotes this relation), as well as between participants of local religious feasts who donate money for this purpose'

Table 17: Forms of address used in Linhó (Lisbon).

\begin{tabular}{|c|c|c|c|c|c|c|}
\hline Categories & ২-> young & <-> equals & $>$ parents & $>$ older & > strangers & > superiors \\
\hline appellative & & & $\begin{array}{l}\text { paizinho, } \\
\text { mãezinha }\end{array}$ & tio/a & & \\
\hline actantial & & você & você, tu & & você & você? \\
\hline
\end{tabular}

ILB-2092/63_Linhó/São Pedro de Penaferrim/Sintra/LISBOA [Q ${ }^{21962]}$

(14) Pragal (Setúbal)

371: Quasi todas as crianças dizem: paisinho, mãizinha. É costume tratarem por você.

'Almost all children address their parents with paizinho, mãezinha. They habitually use você'

Table 18: Forms of address used in Pragal (Setúbal).

\begin{tabular}{|c|c|c|c|c|c|c|}
\hline Categories & <-> young & <-> equals & $>$ parents & > older & > strangers & > superiors \\
\hline appellative & & & $\begin{array}{l}\text { paizinho, } \\
\text { mãezinha }\end{array}$ & & & \\
\hline actantial & & & você & & & \\
\hline
\end{tabular}

ILB-2236/42_Pragal/Santiago/Almada/SETÚBAL [Q 1942]

(15) Madalena do Mar (Funchal)

371: Chamam: mê pai ou mi-pai, mê padrinho, etc. Quando falam com êles tratamnos por amecê. [...] Não empregam o senhor. Para o povo é tudo irmão.

'Children use variants of 'my father', 'my godfather', etc. When they speak to them they use amecê (= reduced vossamecê). They do not use o senhor. For the general public everybody is called irmão 'brother" 
Table 19: Forms of address used in Madalena do Mar (Funchal).

\begin{tabular}{|c|c|c|c|c|c|c|}
\hline Categories & <-> young & <-> equals & $>$ parents & > older & > strangers & > superiors \\
\hline appellative & & irmão & $m \hat{e}-/ m i-p a i$ & & & \\
\hline actantial & & & amecê & & & \\
\hline
\end{tabular}

ILB-Ilhas 7/42_Madalena do Mar/M. do M./Ponta do Sol/FUNCHAL [Q 1942]

Table 20 provides a synthesis of the most common forms of address used in different districts of Portugal. Italics are used for the most commonly used forms.

Table 20: Synthesis: Common forms of address in the districts of Portugal.

\begin{tabular}{|c|c|c|c|}
\hline $\begin{array}{l}\text { North (1) } \\
\text { to South (8) } \\
\text { plus islands (9) }\end{array}$ & West & Middle & East \\
\hline 1 & $\begin{array}{l}\text { VIANA DO CASTELO } \\
\text { bocê/você } \\
\text { bomecê/vomecê } \\
\text { bossemecê/vossemecê } \\
\text { buociê, buossameciê }\end{array}$ & & $\begin{array}{l}\text { BRAGANÇA } \\
\text { bocê/você } \\
\text { bomecê/vomecê } \\
\text { bossemecê/vossemecê } \\
\text { bacê, bancê, boncê, bõucê }\end{array}$ \\
\hline 2 & $\begin{array}{l}\text { PORTO } \\
\text { bocê/você } \\
\text { bomecê/vomecêe } \\
\text { bossemecê/vossemecê } \\
\text { bòcê } \\
\text { bòmeciê }\end{array}$ & $\begin{array}{l}\text { BRAGA } \\
\text { bocê/você } \\
\text { bomecê/vomecê } \\
\text { bossemecê/ } \\
\text { vossemecêe } \\
\text { bòcê } \\
\text { bòsjê }\end{array}$ & $\begin{array}{l}\text { VILA REAL } \\
\text { bocê/você } \\
\text { bomecê/vomecê } \\
\text { bossemecê/vossemecê } \\
\text { bocia } \\
\text { boncê, vancê }\end{array}$ \\
\hline 3 & $\begin{array}{l}\text { AVEIRO } \\
\text { bocê/você } \\
\text { bomecê/vomecê } \\
\text { bossemecê/vossemecê } \\
\text { bocêê, boceia } \\
\text { bocemecê [= bossemecê] } \\
\text { <bwòsnề* }\end{array}$ & $\begin{array}{l}\text { VISEU } \\
\text { bocê/você } \\
\text { bomecê/vomecê } \\
\text { bossemecê/ } \\
\text { vossemecê } \\
\text { bomcê [< bomecê] }\end{array}$ & $\begin{array}{l}\text { GUARDA } \\
\text { bocê/você } \\
\text { bomecê/vomecê } \\
\text { bossemecê/vossemecê } \\
\text { bòcê }\end{array}$ \\
\hline 4 & $\begin{array}{l}\text { COIMBRA } \\
\text { bocê/você } \\
\text { bomecê/vomecê } \\
\text { bossemecê/vossemecê } \\
\text { bacê } \\
\text { bocês - bocêses } \\
\text { [= plural-extension] } \\
\text { bomecê, bomcê } \\
\text { vancê (Penacova) }\end{array}$ & & \\
\hline
\end{tabular}


Table 20 (continued)

\begin{tabular}{|c|c|c|c|}
\hline $\begin{array}{l}\text { North (1) } \\
\text { to South (8) } \\
\text { plus islands (9) }\end{array}$ & West & Middle & East \\
\hline 5 & $\begin{array}{l}\text { LEIRIA } \\
\text { bocê/você } \\
\text { bomecê/vomecê } \\
\text { bossemecê/vossemecê } \\
\text { bacé }\end{array}$ & & $\begin{array}{l}\text { CASTELO BRANCO } \\
\text { bocê/você } \\
\text { bomecê/vomecêe } \\
\text { bossemecê/vossemecê } \\
\text { bocé } \\
\text { bossemecê } \\
\text { vom'cê [< vomecê] } \\
\text { vomessaj, vomessaji } \\
\text { vossaj, vossaji } \\
\text { vossamecé } \\
\text { vossemecéj, vossemessöj } \\
\text { vossomecê }\end{array}$ \\
\hline 6 & $\begin{array}{l}\text { LISBOA } \\
\text { bocê/você } \\
\text { bomecê/vomecê } \\
\text { bossemecê/vossemecê }\end{array}$ & $\begin{array}{l}\text { SANTARÉM } \\
\text { você } \\
\text { vomecêe } \\
\text { vossemecê } \\
\text { vossemecê } \\
\text { vomcêj } \\
\text { vossemecêj }\end{array}$ & $\begin{array}{l}\text { PORTALEGRE } \\
\text { bocê/você } \\
\text { bomecê/vomecê } \\
\text { bossemecê/vossemecê } \\
\text { bossemecê } \\
\text { bossemê [ILB_R_2225/69] } \\
\text { omecê [Simão 2011, 150] } \\
\text { vossemecê }\end{array}$ \\
\hline 7 & $\begin{array}{l}\text { SETÚBAL } \\
\text { bocê/você } \\
\text { bomecê/vomecêe } \\
\text { bossemecê/vossemecê } \\
\text { bocei - vocêí } \\
\text { vossemecêia }\end{array}$ & $\begin{array}{l}\text { ÉVORA } \\
\text { você } \\
\text { vomecê } \\
\text { vossemecê } \\
\text { vossemecej } \\
\text { vossemeceia }\end{array}$ & $\begin{array}{l}\text { BEJA } \\
\text { você } \\
\text { vomecêe } \\
\text { vossemecê } \\
\text { vomecea } \\
\text { vossemecea, vossemeceia }\end{array}$ \\
\hline 8 & & $\begin{array}{l}\text { FARO } \\
\text { você, vomecê, } \\
\text { vossemecêe } \\
\text { abeceia, amecêa } \\
\text { vocêa } \\
\text { vomeceia } \\
\text { vòssemecêa } \\
\text { voumecê }\end{array}$ & \\
\hline 9 & AÇORES (Horta) vomecêa & & MADEIRA --- \\
\hline
\end{tabular}


Table 21 singles out the most commonly used terms. It thus provides an idea of what may be considered general tendencies of development.

Table 21: Summary of the main forms of address used in the dialects of Portugal.

\begin{tabular}{lll}
\hline Categories & Appellative Forms & Actantial Forms \\
\hline <-> young & First name, e.g. João, Maria & $t u, 2 \mathrm{P}$ \\
\hline <->equals & First name, e.g. João, Maria; irmão & tu, 2P, você, 3P \\
\hline$>$ parents & (ó) $(\mathrm{meu} / \mathrm{mi}$-) (sr.) pai/mãe; paizinho & $\begin{array}{l}\text { o pai/a mãe, você, } \\
\text { vo(sse)mecê, amecê }\end{array}$ \\
\hline > older (in-group) & ó velh(inh)a, tio/a & você, vo(sse)mecêe \\
\hline > strangers & senhor/a & você, v(osse)mecê, o senhor \\
\hline$>$ superiors & patrão, senhora & $\begin{array}{l}\text { vo(sse)mecê, o senhor, } \\
\text { Vossa Excelência }\end{array}$ \\
\hline
\end{tabular}

\subsection{Towards an onomasiological classification of address forms in the ILB}

Table 22 includes more specific onomasiological concepts related to the types of address forms documented in the ILB. The concepts and abbreviations used are as follows:

a) The concept of respect is divided into resp_1 in relation to older people (resp_1a specifying the group of parents and godparents, resp_1b all other older persons) and resp_2 in relation to other superiors;

b) initial bilabial or labiodental consonants are mostly represented by their v-allomorphs;

c) the abbreviations $v c / v m / v m c$ (here and elsewhere in this text) represent você/ vossemecê/vomecê (or other graphic variations of these three);

d) further shorter forms are:

gen. $x+1 / 2 \quad$ one or 2 generations older

óP_vc representing a typical context like ó pai, você quer ...?

oP_quer representing a typical context like o pai quer...?

$o \mathrm{Ful}^{\circ} / \mathrm{aFul}^{a}$ representing a typical context like o João/a Maria

$\mathrm{ti} / \mathrm{a} \mathrm{Ful}{ }^{\mathrm{o} / \mathrm{a}} \quad$ representing a typical context like ti(o) João/ti(a) Maria 


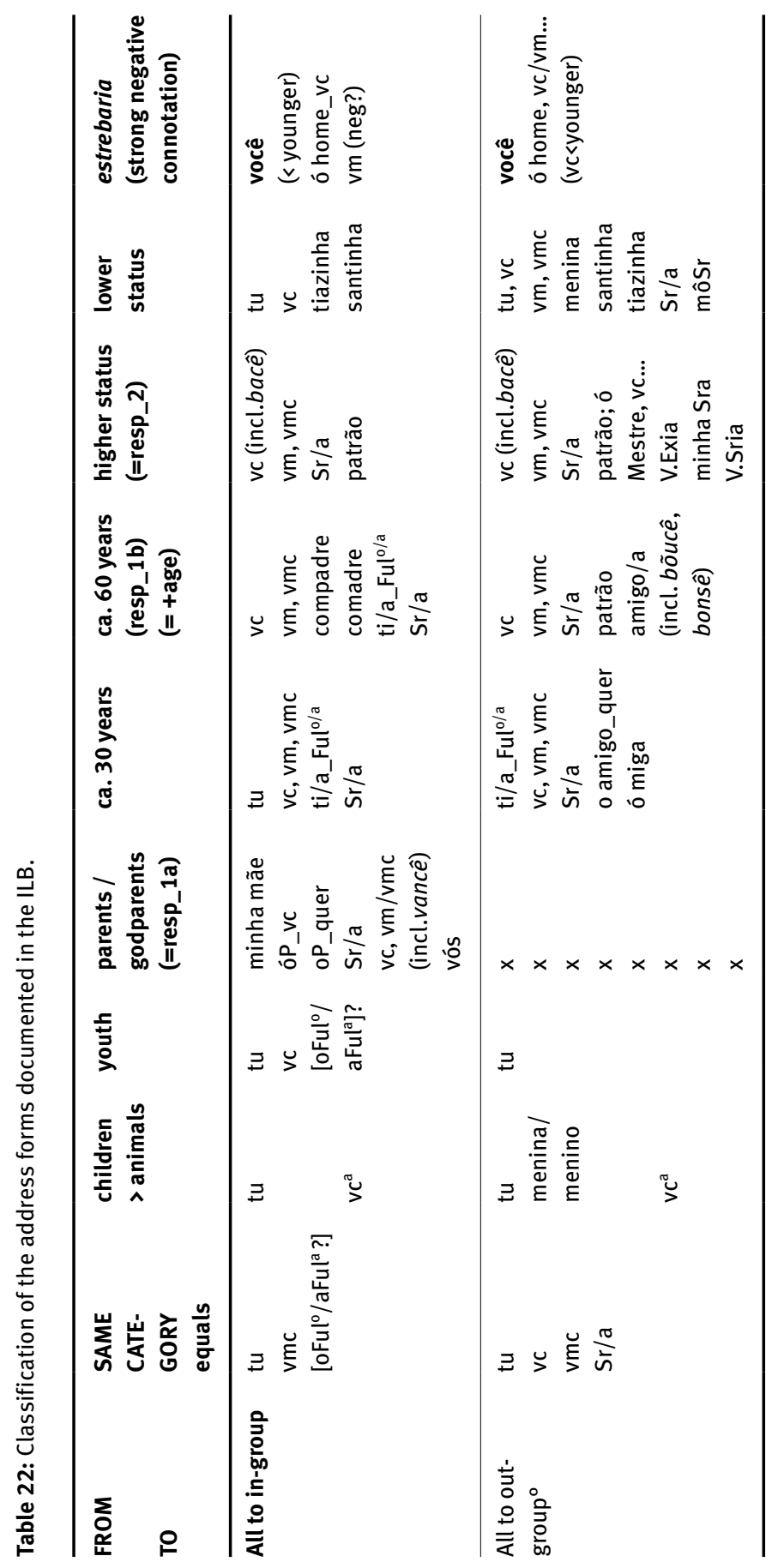




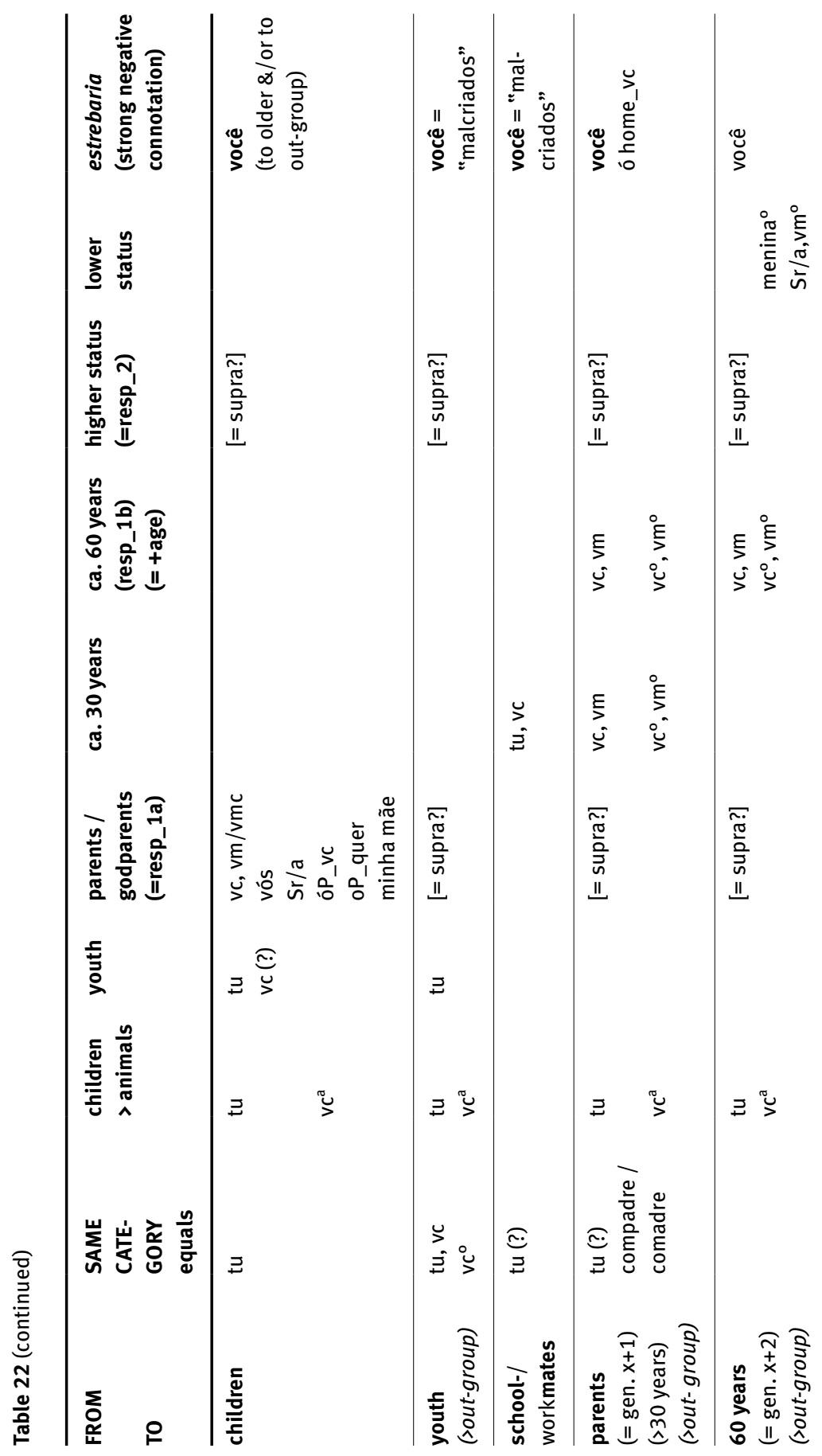


«ֶ

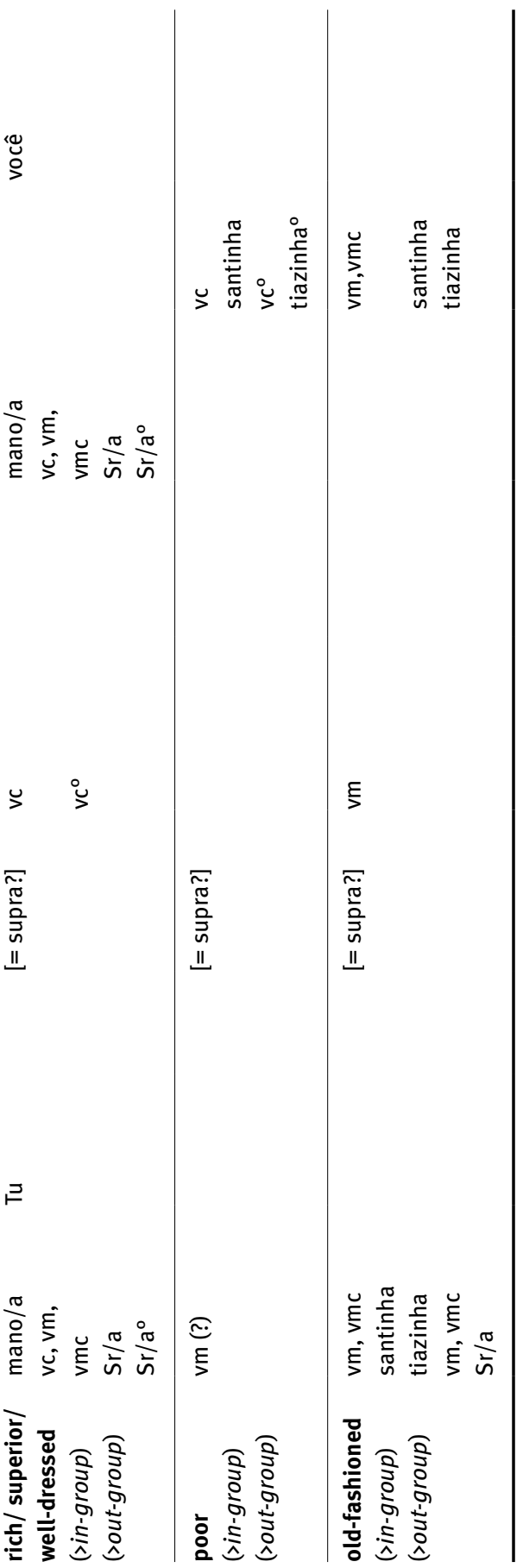


$v c^{a} \quad$ representing use to animals

$v c^{\circ} \quad$ representing use to outsiders (when necessary to be pointed out) estrebaria $^{10}$ serving as a label for common judgements classifying the use of você as "less educated/offensive".

Table 22 seeks to show as clearly as possible the varieties of Portuguese address forms in their conceptual positions, and especially the address form você evaluated according to the context of its use. In parallel with its etymological relatives vossemecê and vomecê, there mostly remains a positive, respectful evaluation when você is situated in a respect marking context like ó pai, você/vo(sse)mecê. However, você also acquires a special value of solidarity (in competition with the use of $t u$ ?) among (mostly younger) equals that prompted older generations and/ or many higher status individuals to label this use as estrebaria. ${ }^{10}$

\section{From Late Latin VOSTRA MERCED to Pt. você - a pronominal pedigree}

The geolinguistic distribution of the você forms (and their variants) in Table 20 will now be reconsidered in a pedigree, trying to establish the possible diachronic sequence of as much of the vossa mercê descendants as possible. For this purpose, Figure 1 presents historic types of VOSTRA MERCED (via vossa mercê) descendants belonging to the vossemecê-você family. The elements have been extracted from the available ILB corpora, and we can take them as a basis for a hypothetical pedigree in terms of diachronic reconstruction from the synchronic variationist data in the ILB. Some of the more or less generalized phonetic spellings of our examples have been normalized by bringing them close to standard (or at least near-standard) Portuguese written conventions (e.g. vocemecê > vossemecê). In order to graphically visualize this pedigree structure, uninterrupted lines are used to show the supposed mainstream, and dotted lines lead to some possible sideline evolutions. All forms in italics in Figure 1 stand for ILB-documented types; "ò" represents an open vowel and "ê" or "ô" a closed one; possible missing links are marked by “*[...]”, and underlining is used to reinforce the distinctness of the forms in italics.

10 Você é estrebaria is a popular expression in Portugal's rural areas, meaning something like 'você is crap'. The DLP (1996) defines estrebaria as follows: "lugar onde se recolhem bestas; cavalariça; (de estrabo, do lat. stabûlu-, estábulo + -aria)", that is, 'stable, barn'. 


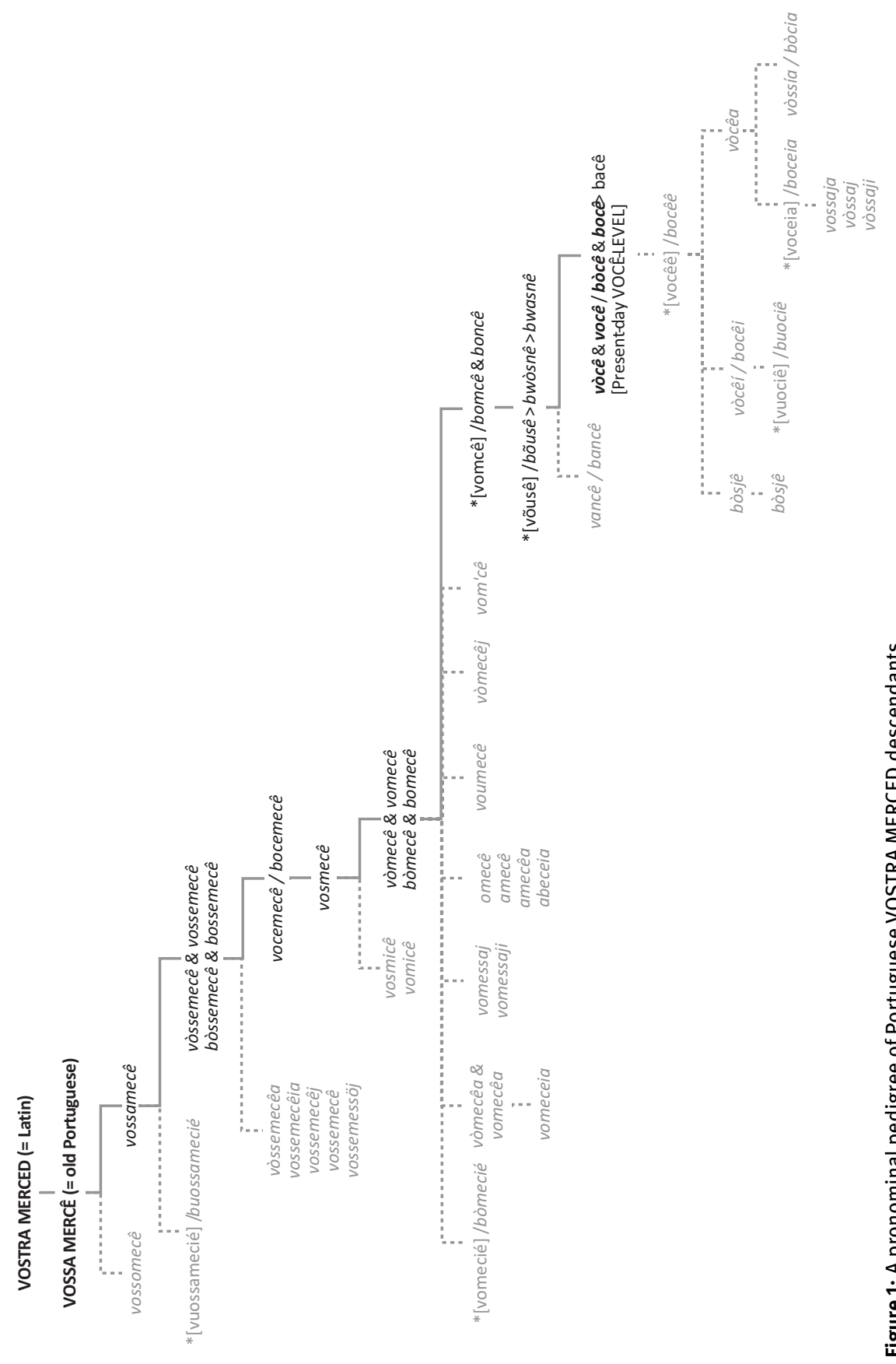




\section{An example of address form choices documented for the District of Viseu}

Table 23 groups the address forms documented in the ILB categorizing their respective use in the District of Viseu (Beira Alta). This District may be seen as representative of the surrounding areas. The Table presents relevant onomasiological categories that mainly separate in-group from out-group addressees (i.e. village insiders vs. outsiders). The documented types of address forms are mostly given by abbreviations which keep the regional marks of [v- : b-] as bilabial or labiodental initial consonants in order to shed light on the diatopic distribution of this phenomenon. Among the subjects asked to fill in the questionnaires, many (especially those completing questionnaires by correspondence from 1942) will have preferred to give the standard orthographic version instead of the genuine local phonetic variation. This means that the $b$-forms appearing in the answers to the questionnaires can be taken as valid evidence of this local phenomenon, while the v-spelling may hide b-pronunciation. The annotations used in the Table 23 are as follows:

$\mathrm{xyz}^{\star}$ (etc.) “*” marking a possible use of the same item in a different context $\mathrm{vc} / \mathrm{bc} \quad$ você/bocê

$\mathrm{vm} / \mathrm{bm} \quad$ vossemecê/bossemecê

$\mathrm{vmc} / \mathrm{bmc} \quad$ vomecê/bomecê

estreb(aria) comments like <você é estrebaria; quando eu nascí já você palha roía>

offs offensive

-old used to/expected by less old/younger people

+old used to/expected by older people

old- used by less old people

old $+\quad$ used by older people

o_pai context o pai/a mãe quer, etc.

óPai_vc context ó pai/mãe, você quer, etc.

$>$ stran(gers) to strangers

>urban to urban people

yng/young younger people (when necessary, marked as $\langle=b y\rangle=,t o,\langle-\rangle$ = between

Table 23 only contains data from questionnaires completed later than 1942 and their respective evaluation, which contain responses about address use in outgroup relations. The original $\S 371$ of the questionnaire was aimed explicitly at 


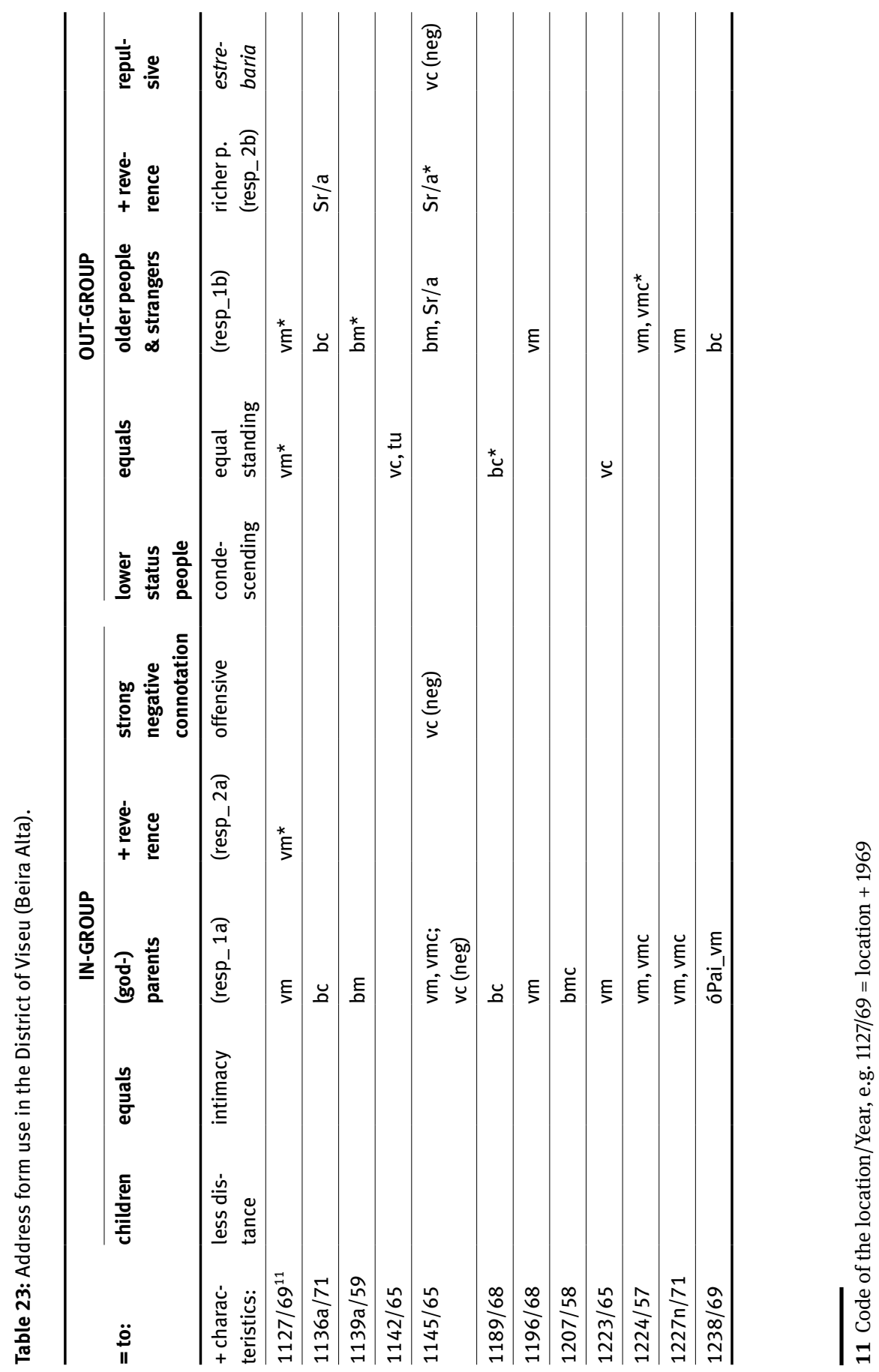




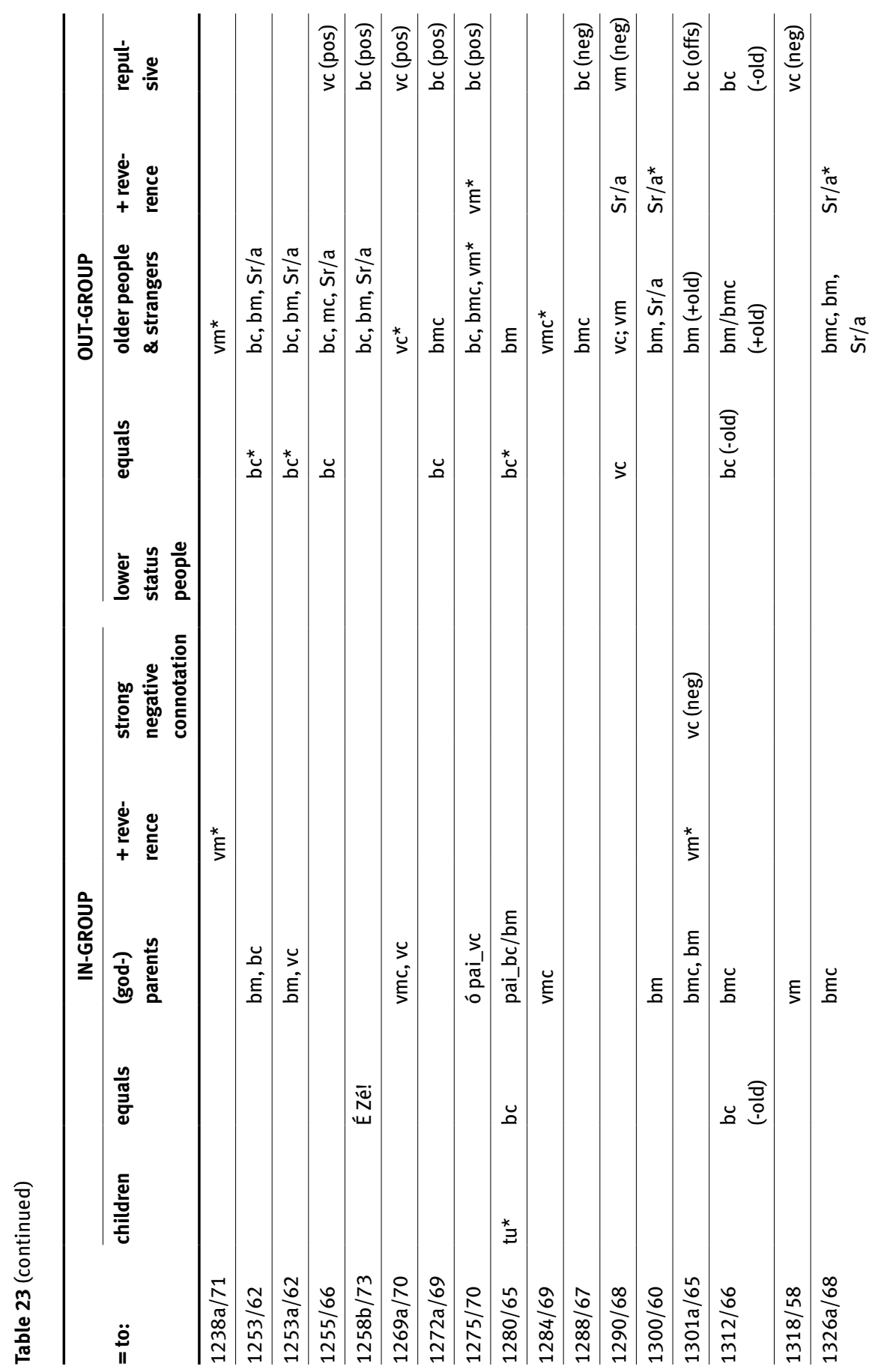




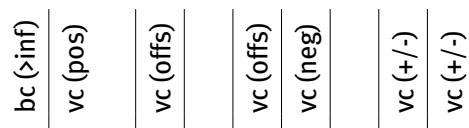

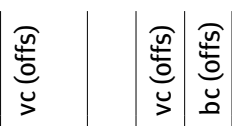

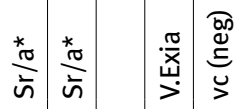

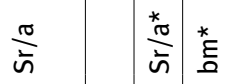

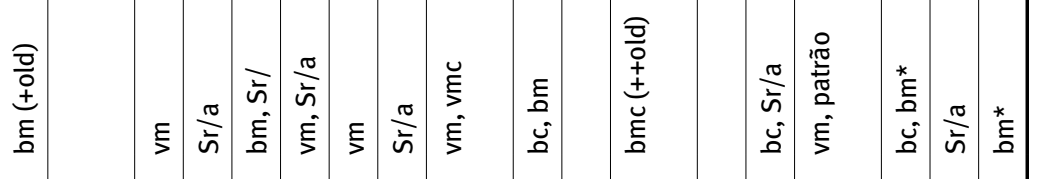

กิ

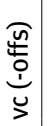

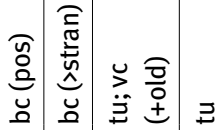

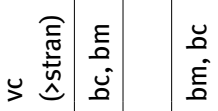

ڤ

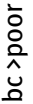

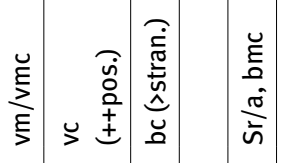

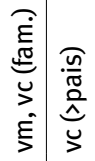

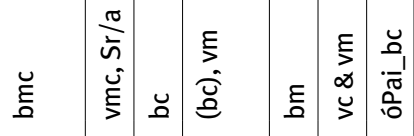

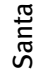

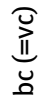

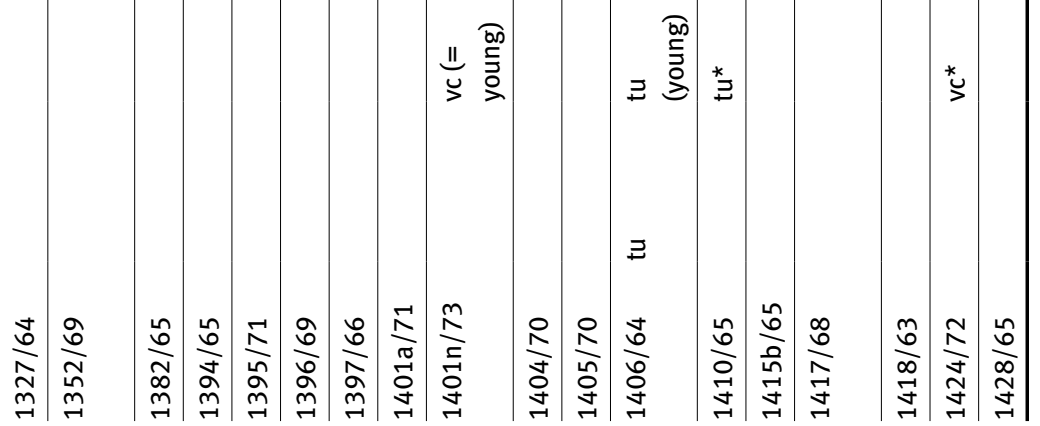




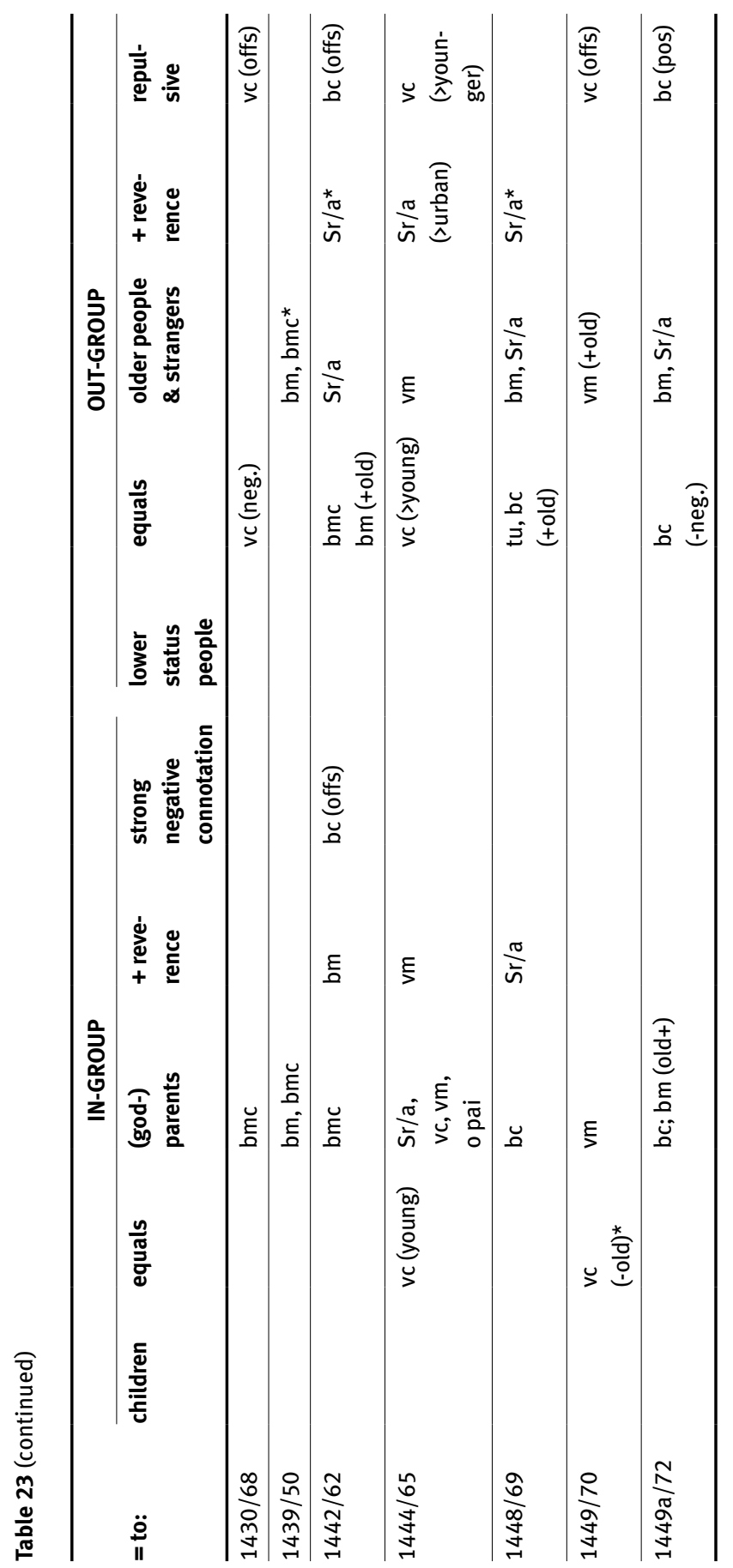


in-group relations, and very few questionnaires had any responses about outgroup uses of address variants. However, Boléo added questions on address use in out-group relations in $\S 371 \mathrm{~b}$ (see Table 3 ) in the first reprint of his second version of the questionnaire edited in 1962 (Boléo 1976: 25, fn. 2).

\section{Diatopic survey of informants' evaluations of você}

\subsection{Informants' evaluations according to district}

Table 24 outlines the most typical evaluations found within each district. In this table, a short characterization follows each district's name in “ $\{. .$.$\} ”. Negative eval-$ uation of VOCÊ is marked by underlining (VOCÊ-neg.), and positive evaluation in bold (VOCÊ-pos.). These evaluations are (partially) marked by “(neg)” or “(pos)”, but mostly using the following gradations: “++, +, +/-, -, --” (where “-” corre-

Table 24: Você evaluations by districts and sectors (see geographical description in Table 20).

\begin{tabular}{|c|c|c|}
\hline West & Middle & East \\
\hline $\begin{array}{l}\text { VIANA DO CASTELO } \\
\text { \{positive in general\} }\end{array}$ & $\begin{array}{l}\text { BRAGA } \\
\text { \{mixed evaluations\} }\end{array}$ & $\begin{array}{l}\text { BRAGANÇA } \\
\text { \{positive with young people\} }\end{array}$ \\
\hline 0013/42: bc (pos.) to parents & 0334/66_b: $\underline{\mathrm{vc}(-)}$ & 0480a/64_b:vc (-) (grumbling > \\
\hline 0017/64: bc (pos.) to parents & 0177/66_b: bc (+) (only equals & children) \\
\hline \& strangers & or inferiors) & 0640a/70_b: $\underline{\mathrm{vc}(-)(>\text { aggressive }}$ \\
\hline 0026/69: bc (pos.) to parents & 0297/63_b: bc (+) (without & $\underline{\text { answers) }}$ \\
\hline \& strangers & great intimacy) & $\overline{0502 / 62 \_b: b c(+/-)(<b o c e ̂}$ \\
\hline 0028/42: bc (pos.) to parents & 0315/64_b: bc (+) (very & é estrebaria>?) \\
\hline 0032a/70: bc (pos.) to & common) & 0509/64_b:vc (+/-) (seldom); \\
\hline strangers & 0232/70: $\underline{b c(+/-)}$ & 0527a/71_b: vc (+) (> equals) \\
\hline 0053/42: bc (pos.) to parents & (ill-mannered to superior) & 0580a/71_b: bc (+) (among \\
\hline 0059/42: bc (pos.) to parents & 0241/69_b: vc (+/-) (offensive & boys) \\
\hline 0073/70: bc (pos.) to & to superiors) & 0586/62_b: $\underline{\mathrm{bc}(-)(>\text { animals })}$ \\
\hline strangers & 0246/65_a: vc (to avoid when & 0588a/71_b: bc (+/-) ( $>$ poor $)$ \\
\hline 0112/64: bc (pos.) to parents & respectful) & 0644a/71_b: bc (+) (between \\
\hline 0118/65: bc (pos.) to parents & 0270/62_b: bc (+/-) (equals, & younger speakers) \\
\hline \& strangers & no intimacy) & 0650/62_b: $\underline{\mathrm{vc}(-) \text { (disrespect) }}$ \\
\hline 0128/65: bc (pos.) to parents & 0146/68_b: bc (-) (<bòsê è & 0561/65_b: bc(+) \\
\hline 0131/67: bc (pos.) to parents & burro 'stupid'>) & (= most common) \\
\hline 0132/69: bc (pos.) to parents & & \\
\hline
\end{tabular}


Table 24 (continued)

\begin{tabular}{|c|c|c|}
\hline West & Middle & East \\
\hline $\begin{array}{l}\text { PORTO } \\
\text { \{rather negative evaluations\} }\end{array}$ & $\begin{array}{l}\text { VISEU } \\
\text { \{mixed evaluations\} }\end{array}$ & $\begin{array}{l}\text { VILA REAL } \\
\text { \{reserved evaluations?\} }\end{array}$ \\
\hline \multicolumn{3}{|l|}{ 0675/64_a/b: bc (-) } \\
\hline $\begin{array}{l}\text { 0896/67_a: bc } \overline{(++)} \text { <ò pài, } \\
\text { bosê> } \\
\text { 0896/67_b: bc (+) } \\
\text { 0730/42: vc (+) = high status } \\
\text { + <manos> } \\
\text { 0675/64_b: } \underline{\text { bc (-) }} \\
\text { 0675/64_b: } \underline{\text { bc (-) }}\end{array}$ & 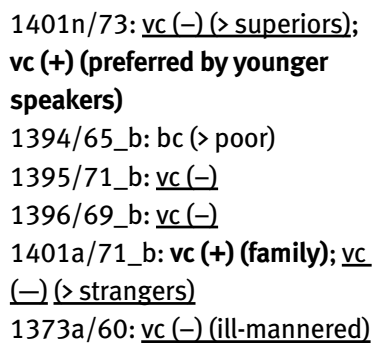 & 0381a/71: vc (-) (seldom) \\
\hline $\begin{array}{l}\text { AVEIRO } \\
\text { \{generally positive } \\
\text { evaluations\} } \\
\text { 1026/65_b: bc (-) } \\
\text { 0954/66_a: bc (++) } \\
\text { 0955/63_b: bc (> pais) } \\
\text { 0963/68_b: bc/Sr (++) } \\
\text { 1067a/64_b: vc (+) ó mestre, } \\
\text { você = +'familiar’ } \\
\text { 0910a/71_b: bc (+) } \\
\text { 0912/42: vc (-) (> 'o pai') } \\
\text { 0954/66_a: bc (++) (neta } \\
\text { para mãe \& avó) } \\
\text { 0977/42: vc (++) } \\
\text { 1069/72_b: vc (+/-) } \\
\text { 0977/42: vc (++) }\end{array}$ & 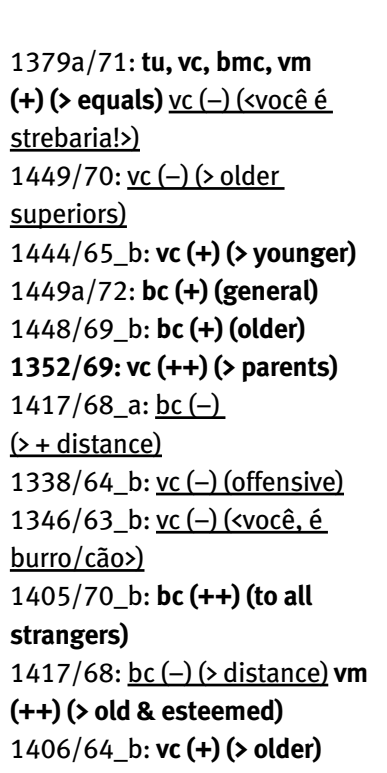 & 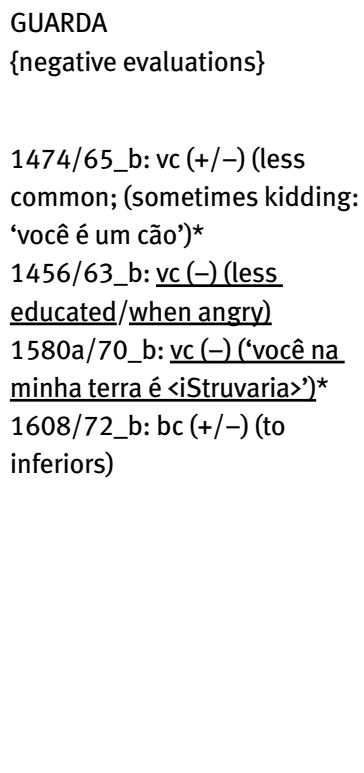 \\
\hline
\end{tabular}


Table 24 (continued)

\begin{tabular}{|c|c|c|}
\hline West & Middle & East \\
\hline $\begin{array}{l}\text { COIMBRA } \\
\text { \{mixed evaluations\} } \\
\text { 1789/64_a: vc (-); } \\
\text { 1789/64_b: vc (+/-) } \\
\text { 1622a/70_b: vc (+)/bc } \\
\text { ( lavrador) } \\
\text { 1631/68_b: bc (+) } \\
\text { (in-group)/bc(-) (out-group) } \\
\text { 1631/68_b: bc (+) } \\
\text { (in-group)/bc (-) } \\
\text { (out-group) } \\
\text { 1679/65_b: vc (+/-) } \\
\text { 1683/66_b: bc (-)('uma má } \\
\text { palavra') } \\
\text { 1683a/70_b: bc (+/-) } \\
\text { 1687/55_b: bc (-) } \\
\text { (<iStrubaria>) } \\
\text { 1689b/54: bc (++) (<bacê>) } \\
\text { 1690/54: bc (++) (<bacề) } \\
\text { 1693/67_b: bc (-) } \\
\text { (>estranhos) }\end{array}$ & 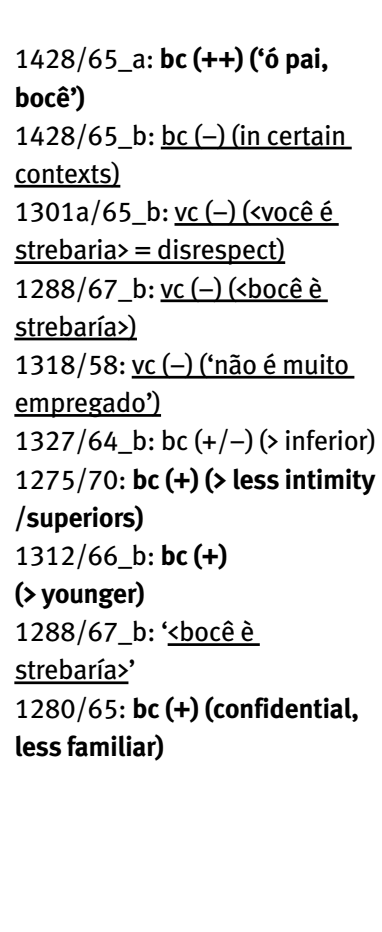 & 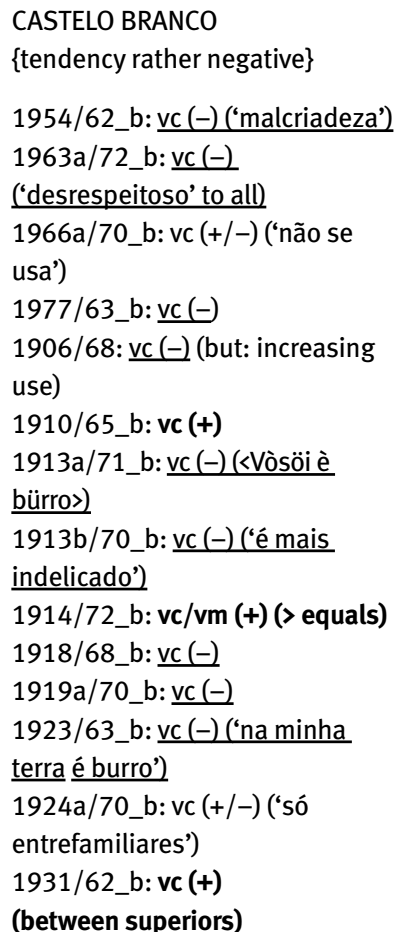 \\
\hline $\begin{array}{l}\text { 1701/65_b: bc (++) (>older, } \\
\text { same class) } \\
\text { 1701a/68_b: bc (+) (<bacê>) } \\
\text { (friends) } \\
\text { 1702/65_b: bc (+) } \\
\text { ('generalizado') } \\
\text { 1631/68_b: bc (+/-) } \\
\text { (>known) } \\
\text { 1616b_b: bc (-) }\end{array}$ & & $\begin{array}{l}\text { I1946/72_b: } \underline{\mathrm{vc}(-)(=\text { blaming }} \\
\text { young people) } \\
\text { I1950/62_b: } \underline{\mathrm{vc}(-) \text { ('nunca se }} \\
\underline{\text { usa') }} \\
\text { 1933a/72_b: } \underline{\mathrm{bc}(-)(<e ́ \mathrm{a}} \\
\text { fidalgue ou zangado>)* } \\
\text { 2024/70_a: vc (+) ('fino para } \\
\text { padrinho jovem')/vc (-) (never to } \\
\text { older people) } \\
\text { 2024/70_b: vc (++) ('para gente } \\
\text { fina') }\end{array}$ \\
\hline
\end{tabular}


Table 24 (continued)

\begin{tabular}{|c|c|c|}
\hline West & Middle & East \\
\hline $\begin{array}{l}\text { 1862/64_b: vc (+/-) ('muito } \\
\text { pouco usado') } \\
\text { 1824/67_a: bc; } \\
\text { 1824/67_b: bc (+) } \\
\text { (mais empregado) } \\
\text { 1839/64_b: bc (> equal) } \\
\text { 1842/65_b: vc (<basé>) } \\
\text { (shows disrespect) } \\
\text { 1843/68_b: vc (+) (boys \& } \\
\text { girls) } \\
\text { 1852/69_b: vc (+) } \\
\text { 1855/64_a: vc (+) }\end{array}$ & 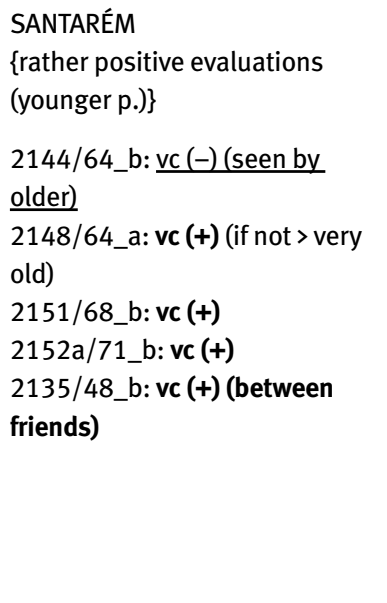 & 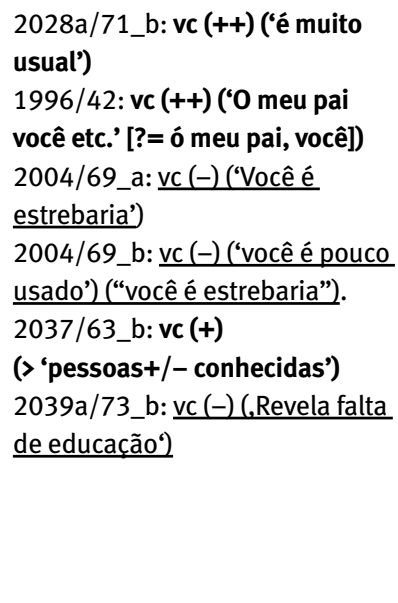 \\
\hline $\begin{array}{l}\text { LISBOA } \\
\text { \{rather positive evaluations?\} } \\
\text { 2091/68_a: vc (+) }\end{array}$ & $\begin{array}{l}\text { ÉVORA } \\
\text { \{rather positive evaluations } \\
\text { (younger p.)\} } \\
\text { 2288/72_b: } \underline{\mathrm{vc}(-) \text { ('você é arte }} \\
\underline{\text { de escandalizar') }} \\
2279 / 72 \text { b: } \underline{\mathrm{vc}(-) \text { (offs. for }} \\
\underline{\text { older); } v c(+) \text { (youth) }}\end{array}$ & $\begin{array}{l}\text { 2225/69_b: bc (+) ('empregam } \\
\text { muito') /bc ('as camadas mais } \\
\text { idosas nãogostam') } \\
\text { 2196a/70_b: } \underline{\text { vc (-) (offs.> }} \\
\text { strangers) }\end{array}$ \\
\hline $\begin{array}{l}\text { SETÚBAL } \\
\text { \{rather positive evaluations?\} } \\
\text { 2238/42: vc (+) (from young } \\
\text { people) }\end{array}$ & $\begin{array}{l}\text { 2295/64_b: vc (-) (when angry) } \\
\text { 2308/70_b: } \leq \text { vocêi não se usa }{ }^{*} \\
\text { 2284/65_b: ‘diz-se que você é } \\
\text { estrebaria' }\end{array}$ & $\begin{array}{l}\text { BEJA } \\
\text { \{rather reserved evaluations?\} }\end{array}$ \\
\hline AÇORES & $\begin{array}{l}\text { FARO } \\
\text { \{rather positive evaluations\} } \\
\text { 2395/63: vc }(+) \text { (> same age) } \\
\text { 2399a/70: vc }(+) \text { (> acquainted) }\end{array}$ & MADEIRA \\
\hline
\end{tabular}

sponds to algo provocante 'middly offensive' and "--" to ofensivo 'offensive'). We will use part of the original ILB differentiation (cf. ILB $\S 371$ and 371b), but mark by “_a” comments belonging to $\S 371$ (targeting insiders' use) and by “_b” those belonging to $\S 371 \mathrm{~b}$ (added to the questionnaire only after 1942 and targeting address use with outsiders). As an illustration, "Bragança-0480a/64_a" refers to family/village in-group, and "Bragança-0480a/64_b” to strangers/village out-group. 
Table 25: Synthesis of Table 24.

\begin{tabular}{|c|c|c|}
\hline $\begin{array}{l}\text { West } \\
\text { Most typical features }\end{array}$ & $\begin{array}{l}\text { Middle } \\
\text { Most typical features }\end{array}$ & $\begin{array}{l}\text { East } \\
\text { Most typical features }\end{array}$ \\
\hline $\begin{array}{l}\text { \{positive evaluations by } \\
\text { younger\} }\end{array}$ & $\begin{array}{l}\text { \{pos.: North = ó pai, você / } \\
\text { South: younger people\} }\end{array}$ & $\begin{array}{l}\text { \{positive evaluations by } \\
\text { younger\} }\end{array}$ \\
\hline VIANA DO CASTELO & BRAGA & BRAGANÇA \\
\hline bc (pos.) to parents \& & bc $(+/-)$ (to equals, no & $\underline{\mathrm{bc}}(+/-)(<$ bocê é estrebaria $>$ ?) \\
\hline strangers & intimity). & bc (+) (between younger) \\
\hline PORTO & VISEU & VILA REAL \\
\hline 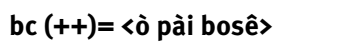 & a: bc (++) ('ó pai, bocề); & $\underline{\mathrm{vc}(-) \text { (seldom) }}$ \\
\hline AVEIRO & $\mathrm{b}: \underline{\mathrm{bc}(-) \text { (in certain contexts) }}$ & GUARDA \\
\hline bc (++) (granddaughter to & SANTARÉM & $\mathrm{b}: \mathrm{vc}(+/-)$ (less common; \\
\hline mother \& grandmother) & a: vc (+) (if not > very old). & (sometimes kidding: <você é \\
\hline COIMBRA & $\mathrm{b}: \mathrm{vc}(-)$ (seen by older). & um cão>) \\
\hline$b c(+)$ (in-group) $\underline{b c(-) \text { (out- }}$ & ÉVORA & CASTELO BRANCO \\
\hline group) & 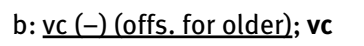 & $\underline{\mathrm{vc}(-) \text { (but: increasing use) }}$ \\
\hline$\overline{\text { LEIRIA }}$ & (+) (youth) & PORTALEGRE \\
\hline vc (+) (boys \& girls) & FARO & b: bc (+) ('empregam muito') \\
\hline LISBOA & vc (+) (> same age) & $\underline{b c}(-)$ ('as camadas mais idosas \\
\hline vc (+) & & não gostam') \\
\hline SETÚBAL & & $\overline{B E J A}$ \\
\hline vc (+) (young people) & & 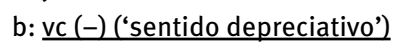 \\
\hline
\end{tabular}

It is challenging to give a concise survey of evaluations of the use of você when trying to base statements on the large amount of address evaluation data in the ILB documents. Thus we cannot design a simple map of a neat north-south and/ or east-west diatopic differentiation. Besides the phonetic (more or less northsouth orientated) variation of initial bilabial vs. labiodental b-/v- (making bocê contrast with você), we can, however, identify a number of essential phenomena.

The more or less typical examples given seem to confirm the not uncommon tendency of younger people (sometimes already in 1942!) to use explicit você more generally than their older neighbors. The latter seem to have still been more orientated by presupposed respectful contexts such as Ó pai, você já ouviu ...? 'You Father, have $\mathrm{you}_{\mathrm{vT}}$ already seen...?' and their equivalents. This positive evaluation by younger people seems to be the case more in the western and southern parts of Portugal.

More exact statements about the present-day distribution of this phenomenon (its increase seems to be evident based on the author's own informal observations over the years) will certainly demand new and very detailed sociolinguistic research. The characteristic geolinguistic differences regarding salient você values results from the fact that, very often, in-group você usage (with family and 
neighborhood insiders) is evaluated more positively than out-group usage (with village outsiders and strangers).

Summing up and taking in account the ILB data reviewed here, I propose the following hypotheses:

1. The list of Portuguese address forms continues to comprise a large inventory ranging from an intimate tu to a very formal Vossa Excelência, together with different verb forms (second and third person to combine with singular and plural);

2. Not all forms are omnipresent, for all speakers or in all situations;

3. The forms may be used to express more or less polite address behavior;

4. Linguistic observation and fieldwork to describe the whole set of actively used Portuguese address forms will have to deal with a range of challenges. For example, when trying to interpret the actual meaning of a seemingly unambiguous statement like Trato-o/a por você 'I address him/her with você', two readings are possible:

(a) Trato-o/a por você can actually refer to an explicit use of você as address pronoun;

(b) In many regions, perhaps more in Northern regions neighboring the town of Porto, speakers saying trato-o/a por você may not imply the use of você itself at all.

In reading (a), we have to consider at least two possible explanations. Firstly, in a context where você takes over from its evolutionary predecessor vossemecê (or vomecê as its more colloquial and/or intimate realization), it will undoubtedly be accepted by everybody as respectful when it is presented, for example, as ó pai, você quer ...? This respect marking context may moreover have been pronounced only once during an ongoing dialogue (or even not at all, but be presupposed as conventional background) to support the positive acceptation of você.

Secondly, apparently, the use of the address pronoun você (as had already been the case with vossemecê and vomecê, both of which did not lose - with very few exceptions - their positive values as a respectful address) was freed from an obligatory respect marking context (accompanied by a vocative like ó Fulano, ... or equivalents).

In some milieus, as represented, for example, by fishermen or muleteers, ${ }^{12}$ besides the continuing intimate (or family bound) $t u$ of solidarity, the use of você (besides or instead of $t u$ ?) seems to have become an expanding marker of solidarity not only for lower status workers. The same lower status speakers,

12 Pt. almocreves - for their historic professional conditions, see, e.g., the novel Terras do Demo by Aquilino Ribeiro (2012). 
however, may have been disgusted when higher status representatives (excepting perhaps their direct superiors) addressed them by an explicit você. This specific solidarity-based value may find its echo in notorious address blaming formulas like você é estrebaria, still to be heard particularly in the northern parts of Portugal. As original sources for those statements we may imagine, among others, primary school teachers and clergymen ("their masters' voice”) who were influenced by their own experience and pedagogical studies in urban centers (mostly orientated towards the standards of Lisbon/Coimbra/Porto). So they may have been propagating their respective cultural and language norms.

In reading (b), one has to bear in mind that nominal forms found their place in actantial positions, as in O pai quer .../O senhor Fulano quer .../o João/a Maria quer ..., etc., with their deictic function paralleling other paradigmatic elements that we commonly call pronouns. These nominal forms can most easily replace a você meant with disgust. This tendency seems to apply rather for certain higher middle-class individuals - who partly had also been used to addressing their siblings by mano 'brother' and mana 'sister'- and all those pupils influenced by their teachers' judgements. This use has presumably originally been established in and around the town of Porto.

\section{Concluding remarks}

Taking in account the rich ILB data and our attempts to discover diachrony within (a relative) synchrony with regard to special forms and modes of Portuguese address conventions, what sort of methodological approach can be proposed? We should perhaps not restrict our analysis to geolinguistic, sociolinguistic and transgenerational variation (see Endruschat \& Schmidt-Radefeldt 2015: 214-240), and search instead for another type of explanation. This makes it difficult to find a way out of this complex and dynamic network - not least for the inhabitants of Portugal themselves: it is remarkable how easily Portuguese people speak about their address uncertainties or their experiences in general. Looking at heuristic categories such as isoglosses, traditionally delimiting language islands - based on phonetic, lexical, or other criteria - promises even better access to that multiplicity of rapidly expanding address subsystems that existed all over 20th century Portugal.

There are cultural observers who view as a special Portuguese phenomenon the impressive socio-cultural coexistence of different ages or historical periods up to the present day. The German journalist, author and poet Hans Magnus Enzensberger, alluding to the notorious synchronic coexistence of historical ves- 
tiges in present-day Portugal, proposed Isochrones to describe possible features of a topology of time. These should describe islands of time paralleling geographical topology (Enzensberger 1986: 49-50).

In accordance with this characterization, I would like to assert for 20th century Portugal (and probably not only as a phenomenon limited to Portugal) the existence of numerous many-layered islands of address-norm systems. These could be understood as being delimited by socioglosses defining address domains which are overlapping and exchanging with others, as individual speakers may, at least partly, participate in different address systems. My terminological proposal of socioglosses owes something to a similar effort in the domain of modality constructions by Franco Benucci, speaking of faisceaux de chronoglosses 'bundles of diachronic isoglosses' (Benucci 1988: 6).

These conventional address islands - delimited and perhaps connected by the respective socioglosses - are certainly subject to continuous conflicts with each other and with educational address standards suggested by teachers or other authorities. These authorities will have received their orientation from layers of society of so-called higher status. In any case, further, more detailed studies will be required to more fully analyze the address complexes (or islands) documented by ILB data.

\section{References}

Benucci, Franco. 1988. Les constructions modales du français des Serments de Strasbourg à nos jours: une analyse syntaxique. PhD thesis. University of Padova. Quoted from: Marc St-Pierre, Daniel Gosselin, Monique Lemieux \& Marthe Faribault. 1991. Le temps recouvré: De la pertinence d'une constitution de corpus; méthodologie et usage. Revue québécoise de linguistique 202. 265. www.erudit.org. (21 June, 2017).

Boléo, Manuel Paiva. 1942/1974. O estudo dos dialectos e falares portugueses. (Um inquérito linguístico). Coimbra. Reprinted in Estudos de linguística portuguesa e românica, 1974, vol.1,1, 1-43. Coimbra: Acta Universitatis Conimbrigensis.

Boléo, Manuel Paiva. 1959. Amostra dos materiais do dicionário dos falares portugueses. Coimbra: published by the author.

Boléo, Manuel Paiva. 1971a. Materiais do "Dicionário dos falares portugueses modernos" e seu confronto com o "Grande dicionário da língua portuguesa" de Morais. Coimbra: published by the author.

Boléo, Manuel Paiva. 1971b. Lista das teses de licenciatura em linguística portuguesa (orientadas desde 1942 até 1971). Coimbra: Faculdade de Letras da Universidade de Coimbra - Instituto de Estudos Românicos.

Boléo, Manuel Paiva. 1974. Estudos de linguística portuguesa e românica, vol. 1,1. Coimbra: Acta Universitatis Conimbrigensis. 
Boléo, Manuel Paiva. 1976. Vida do Instituto de Estudos Românicos (1972-1974). Revista de Filologia Portuguesa 16, 1-2.

Boléo, Manuel Paiva. 1979. Vida do Instituto de Estudos Românicos (1975-1979). Revista de Filologia Portuguesa 17.

Brown, Penelope \& Stephen Levinson. 1987. Politeness: Some universals in language use. Cambridge: Cambridge University Press.

Bühler, Karl. 1967. El yo y el tú. In Teoría del lenguaje, 184-191. Madrid: Selecta de Revista de Occidente.

Clyne, Michael, Catrin Norrby \& Jane Warren. 2009. Language and human relations. Styles of address in contemporary language. Cambridge: Cambridge University Press.

de Oliveira, Sandi Michele. 2009. Negotiating identity, conflict, and cooperation within a strategic model of address. In Ann Denis \& Devorah Kalekin-Fishman (eds.), Contemporary sociology. Conflict, competition, cooperation, 416-432. Los Angeles: Sage.

DLP. 1996. Dicionário [electrónico profissional] da Língua Portuguesa. Porto: Porto Editora Multimédia.

Endruschat, Annette \& Jürgen Schmidt-Radefeldt. 2015. Introdução básica à linguística do português. Lisbon: Colibri.

Enzensberger, Hans Magnus. 1986. Portugiesische Grübeleien. Die Zeit 40 (26.9.1986). 49-56.

Gibbons, John. 1984. Não criei musgo. Retrato de uma aldeia transmontana. Translated from: “I gathered no Moss", Coleja 1939. Bragança: Câmara de Carrazeda de Ansiães.

Glück, Helmut \& Kristine Koch. 1998. Du oder Sie. Anredekonventionen in Deutschland und in anderen Ländern. Der Sprachdienst 1. 1-9.

Goffman, Erving. 1959. The presentation of self in everyday life, Garden City, N.Y.: Doubleday. Hammermüller, Gunther. 1980. Você é estrubaria? Iberoromania 12. 30-40.

Hammermüller, Gunther. 1995. O I.L.B. à margem dum Atlas Linguístico de Portugal? In M. Fátima Viegas Brauer-Figueiredo (ed.), Actas do $4^{\circ}$ Congresso da Associação Internacional de Lusitanistas, 131-144. Lisbon/Porto/Coimbra: LIDEL.

Hammermüller, Gunther. 2010. Evolución de las formas de tratamiento del español medieval hasta el siglo XVI. In Martin Hummel, Bettina Kluge \& María Eugenia Vásquez Laslop (eds.), Formas y fórmulas de tratamiento en el mundo hispánico, 507-529. México DF.: El Colegio de México/Universität Graz.

Hammermüller, Gunther. 2011. Insekten auf einem Datenfriedhof - Aufgespürt in den Relatórios des I.L.B. In Annette Endruschat \& Vera Ferreira (eds.), Sprachdokumentation und Korpuslinguistik - Forschungsstand und Anwendung, 221-236. Munich: Martin Meidenbauer.

Heger, Klaus. 1965. Personale Deixis und grammatische Person. Zeitschrift für Romanische Philologie 81. 77-97.

Langenscheidt Online Wörterbücher. de.langenscheidt.com (11 June, 2017).

Lüdtke, Helmut. 2009. Der Ursprung der romanischen Sprachen: eine Geschichte der sprachlichen Kommunikation. Second edition. Kiel: Westensee-Verlag.

Matias, Fátima de Rezende. 1978. Inquérito linguístico. Questionário organizado por Manuel de Paiva Boléo. Third edition. Aveiro.

Ribeiro, Aquilino. 2012 [1905]. Terras do Demo. Lisbon: Bertrand.

Ribeiro, Aquilino. 2015 [1943]. Volfrâmio. Lisbon: Bertrand.

Simão, Teresa Susana Bengala. 2011. O falar de Marvão. Pronúncia, vocabulário, alcunhas, ditados e provérbios populares. Lisbon: Colibri.

Stanford encyclopedia of philosophy. plato.Stanford.edu (23 May, 2017). 
